\title{
Article \\ Cope or Perish? Managing Tipping Points in Developing Coping Strategies for Emergency Response during the First Wave of the COVID-19 Outbreak in Europe
}

\author{
Tom van der Voorn $1, * \mathbb{C}$ and Martin de Jong $2,3,4$ (i) \\ 1 Institute of Environmental Systems Research, University of Osnabrück, Barbarastr. 12, \\ D-49069 Osnabrück, Germany \\ 2 Erasmus School of Law, Erasmus University Rotterdam, 3000 DR Rotterdam, The Netherlands; \\ w.m.jong@law.eur.nl \\ 3 Rotterdam School of Management, Erasmus University Rotterdam, 3000 DR Rotterdam, The Netherlands \\ 4 Institute for Global Public Policy, Fudan University, Shanghai 200433, China \\ * Correspondence: tvanderv@uni-osnabrueck.de
}

check for updates

Citation: van der Voorn, T.; de Jong, M. Cope or Perish? Managing Tipping Points in Developing Coping Strategies for Emergency Response during the First Wave of the COVID-19 Outbreak in Europe. COVID 2021, 1, 39-70. https:/ / doi.org/10.3390/covid1010005

Academic Editors: Ajeet Kaushik and Joan Puig-Barberà

Received: 18 April 2021

Accepted: 23 June 2021

Published: 29 June 2021

Publisher's Note: MDPI stays neutral with regard to jurisdictional claims in published maps and institutional affiliations.

Copyright: (c) 2021 by the authors. Licensee MDPI, Basel, Switzerland. This article is an open access article distributed under the terms and conditions of the Creative Commons Attribution (CC BY) license (https:// creativecommons.org/licenses/by/ $4.0 /)$.

\begin{abstract}
When the first wave of the COVID-19 pandemic started to manifest itself across the globe at an unprecedented pace and magnitude, the various emergency response strategies pursued by highly affected countries in Europe raised many questions about their supposed effectiveness. To contain the outbreak, a rapid and adequate emergency response was vital to control emergent public health risks, but emergency management was challenged by large uncertainty due to many unknowns about crucial determinants of the outbreak, determining the effectiveness of the response, which was often derived from uncertain information. This paper aims to draw lessons from the first wave of the COVID-19 pandemic and it presents a review of strategies for emergency response pursued in eight European countries, including tipping points that triggered strategy shifts in emergency response. The paper shows that: (i) these countries have a culturally determined preference for policy response style (Mediterranean, continental and liberal style) depending on their relative scores on power distance and uncertainty avoidance, which (ii) is reflected in the initially adopted control paradigm and the associated strategy; (iii) Mediterranean countries (Italy, France, Spain) with high levels of power distance and uncertainty avoidance have a tendency to respond to new unknown situations by deploying strong rule-based regulatory systems which offer mental security and social order, whereas continental (Germany and Austria) and liberal countries (the Netherlands, the UK and Sweden) do this to medium and much lower extents.
\end{abstract}

Keywords: COVID-19; tipping points; mitigation strategy; suppression strategy; Europe

\section{Introduction}

By the end of December 2019, several cases of acute respiratory syndrome were reported by the Chinese public health authorities in Wuhan City, China. Chinese researchers soon identified a novel coronavirus as the main causative agent [1]. The disease has, since then, been referred to as coronavirus disease 2019 (COVID-19), and the causative virus was called severe acute respiratory syndrome coronavirus 2 (SARS-CoV-2). The virus belongs to the Coronaviridae family, which has been identified as the etiologic agent of an ongoing pandemic of severe pneumonia known as COVID-19, which has not been previously identified in humans [2]. On 11 February 2020, the World Health Organization (WHO) officially introduced COVID-19, as a shorthand for the coronavirus disease 2019.

The initial outbreak in Wuhan spread rapidly reached other parts of China, and other countries soon followed [3]. Outbreaks and clusters of the disease had been detected in Asia, followed by Europe [4], Australia [5], Africa [6] and the Americas [7] as the latest epicenter during the first wave of the COVID-19 outbreak. 
In Europe, the first wave of the COVID-19 outbreak emerged in the Lombardy region, Italy [8]. From January to March 2020, the number of cases in Europe rose with increasing pace and magnitude in several affected areas, meaning that there was a need for immediate targeted action to control public health risks. The European Centre for Disease Prevention and Control [9] (ECDC) considered the risk of severe disease associated with COVID-19 infection for people in the EU/EEA and UK moderate for the general population, but high for vulnerable people, including older adults and individuals with chronic underlying conditions, based on the probability of community transmission and the impact of the disease. However, the ECDC estimated the risk of the health care system capacity being exceeded in the EU/EEA and the UK in the early stage of the pandemic to be high. The impact and risk assessment on health system capacity was guided by effective infection prevention and control and surge capacity measures. However, the risk of transmission of COVID-19 in health and social institutions with large vulnerable populations was considered high [9]. Therefore, the ECDC argued that the impact of transmission in health and social institutions could benefit from effective infection prevention and control and surge capacity [9].

In order to contain and prevent further spreading of the COVID-19 outbreak in EU/EEA countries, a rapid and adequate emergency response was vital to control public health risks, but emergency management was surrounded by large uncertainty due to many unknowns about crucial determinants of the outbreak, determining its effectiveness. These determinants relate to, among many others, case fatality, the epidemiological situation, the risk associated with COVID-19 for people, the risk of local and widespread national community transmission, the risk of health care system capacities being exceeded in the EU/EEA and the UK, and the risk of transmission of COVID-19 in health and social institutions with large vulnerable populations. These uncertainties burden disease emergency management with a challenging task of preparing a rapid and adequate response often derived from uncertain information.

In addition to uncertainty, the features of COVID-19 rendered the pandemic control equally challenging since the coronavirus was new, in the absence of previous immunity and effective cure or vaccines. Although the mortality rate appeared to be not as high as that of MERS and SARS, a significant number of affected subjects eventually developed severe bilateral pneumonia, which required intensive care treatment. These tipping points combined have the potential to disrupt public health systems even as a modest fraction of the population is affected, leaving most patients with severe pneumonia without crucial life support, and thus leading to much higher fatality rates. In disease control, there are two dominant strategies with distinct underlying paradigms for dealing with a pandemic: mitigation and suppression strategies. Mitigation strategies are rooted in a paradigm, allowing the pandemic to run its course in a controlled way, eventually leading to herd immunity, while at the same time ensuring that the capacity of the public health system is not overcome. Suppression strategies are based on a paradigm of suppressing a pandemic through containment, without building herd immunity. These paradigms can be seen as opposite perspectives, which typically come with strategy tensions as in socioeconomic trade-offs that need to be addressed.

In this paper, we aim to draw lessons from the first wave of the COVID-19 pandemic for emergency response. We do so by reviewing strategies for emergency response pursued in eight European countries, including the changes in boundary conditions (tipping points) that compelled these countries to shift from one strategy to another. For this purpose, we identify the prevailing paradigms these countries initially adopted in their emergency responses. We hypothesize that these countries can be categorized according to their culturally determined preference for a certain control paradigm and policy response style [10]. This classification provides the starting point for our systematic review of strategy development for emergency responses in The Netherlands, Italy, France, Spain, Germany, Austria, the UK and Sweden. This review is guided by the following inquiries: (i) what were the 
game-changing tipping points, (ii) when did they emerge, and (iii) how did they change governments' choice of strategy?

The paper is structured as follows. Section 2 presents a calibrated risk matrix and typology of emergency strategies. Section 3 presents the country cases on strategy development for emergency response, which are compared later in this Section. Section 4 provides a critical reflection on the results, and Section 5 follows up with concluding remarks and recommendations.

\section{Materials and Methods}

\subsection{A Typology of Emergency Strategies}

In the early stages of the COVID-19 pandemic, emergency management organizations need to estimate the basic reproduction number $\left(R_{0}\right)$, or the more real-time effective reproduction number $(\mathrm{Rt})$ for a given population [10]. $R_{0}$ refers to the number of secondary cases caused by the presence of one infected individual in an otherwise fully susceptible, well-mixed population. Rt represents a more practical real-life version of this, which uses real-life data (from diagnostic testing and/or clinical surveillance) to estimate the reproduction number for an ongoing epidemic or pandemic. The objective of any emergency response during the COVID-19 pandemic should be focused on the containment of the virus by employing mitigation strategies that either: (i) reduce $\mathrm{R}_{0}$ by reducing the transmission rate (e.g., via school closure) or the duration of infectiousness (e.g., through antiviral use), or (ii) reduce Rt by reducing the number of susceptible individuals (e.g., by vaccination).

Kwok, Lai, Wei, Wong and Tang [10] describe the following scenarios for the potential spread or decline of a disease, depending on its $R_{0}$ value:

- If $\mathrm{R}_{0}<1$, each existing infection causes less than one new infection. In this case, the disease will decline and eventually cease to exist.

- If $\mathrm{R}_{0}$ equals 1 , each existing infection causes at least one new infection. The disease remains stable, without causing an outbreak or an epidemic.

- If $\mathrm{R}_{0}>1$, each existing infection causes more than one new infection. The disease will rapidly spread, causing an outbreak or epidemic.

A calibrated risk matrix is proposed based on two dimensions (Figure 1). The first dimension relates to the case fatality rate, indicating the proportion of deaths from a certain disease relative to the total number of people diagnosed with the disease for a certain period of time. The second dimension relates to the infection rate, as an estimate of the rate of progress of a disease, based on proportional measures of the extent of infection at different times.

The matrix in Figure 1 categorizes levels of risk into broadly accepted (in green), tolerable (in yellow and orange) or intolerable (in red) bands. For example, a risk that involves a high case fatality rate and is estimated to be 'likely' would clearly fall into the intolerable band (in red) and favor a 'lockdown' as response strategy. The matrix allows for a typology of response strategies for controlling the outbreak, as described in Table 1. Each strategy is rooted in a distinct paradigm, providing guiding principles for dealing with the COVID-19 outbreak. The underlying paradigm of the mitigation strategies is based on the principle of letting the epidemic run its course in a controlled or uncontrolled way, eventually leading to herd immunity, while at the same time ensuring that the capacity of the public health system is not overcome. The underlying paradigm of the suppression strategies advocates the principle of containment through restrictions. For example, national governments can take rigorous social distancing measures such as closing schools and public places, issuing stay-at-home orders, closing non-essential industrial and commercial activities and banning all kinds of non-essential travel. This serves the aim of reducing the reproduction number $\mathrm{R}_{0}$, causing the outbreak to subside. However, containment leaves open the issue of what strategy to adopt once the epidemic has been suppressed, as most of the population remain vulnerable to the virus and thus prone to a second, and possibly even more wave(s) or outbreaks. 


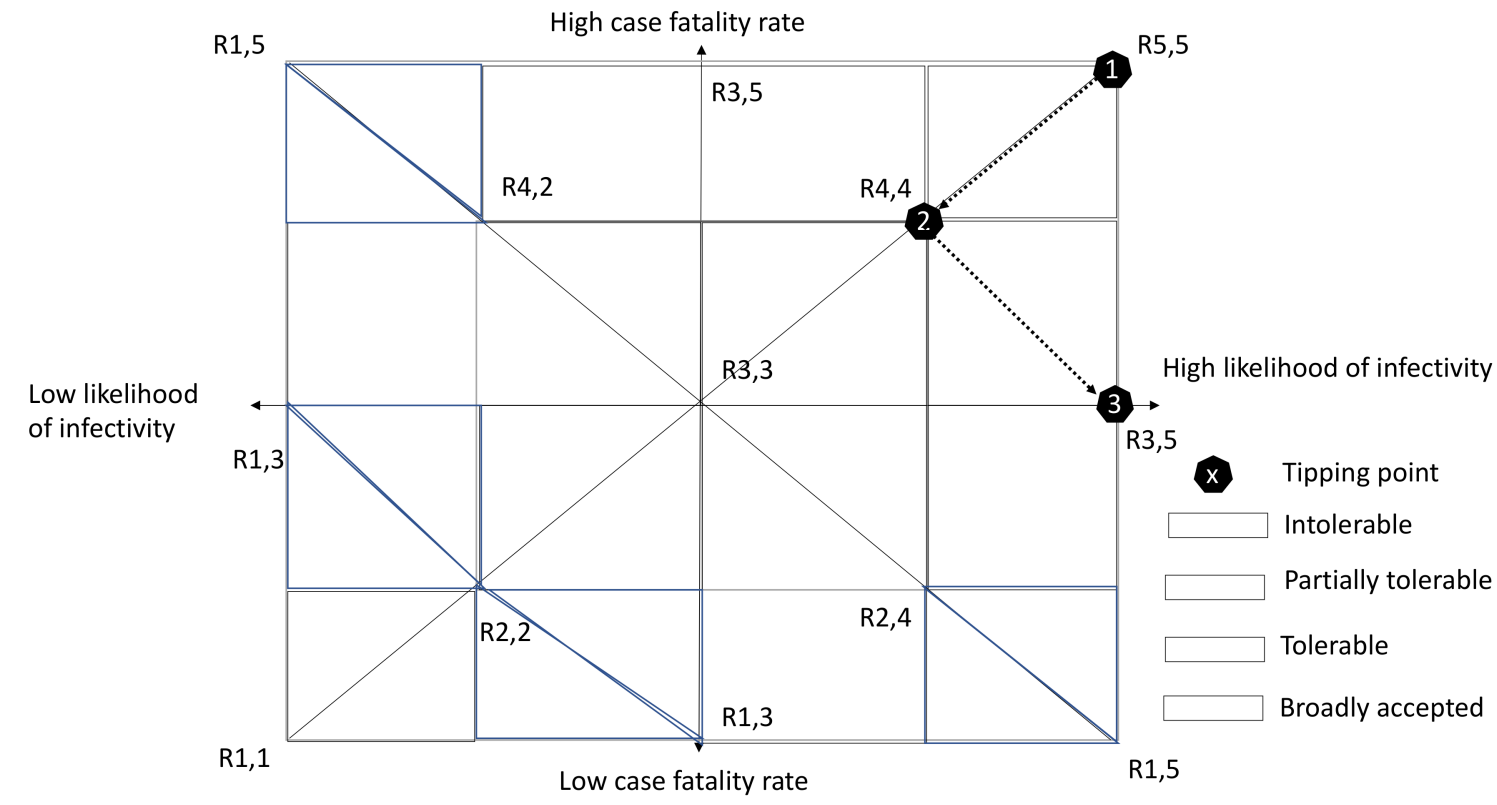

Figure 1. A calibrated risk matrix for emergency response (Adapted from Poljanšek [11]).

Table 1. A typology of emergency response strategies.

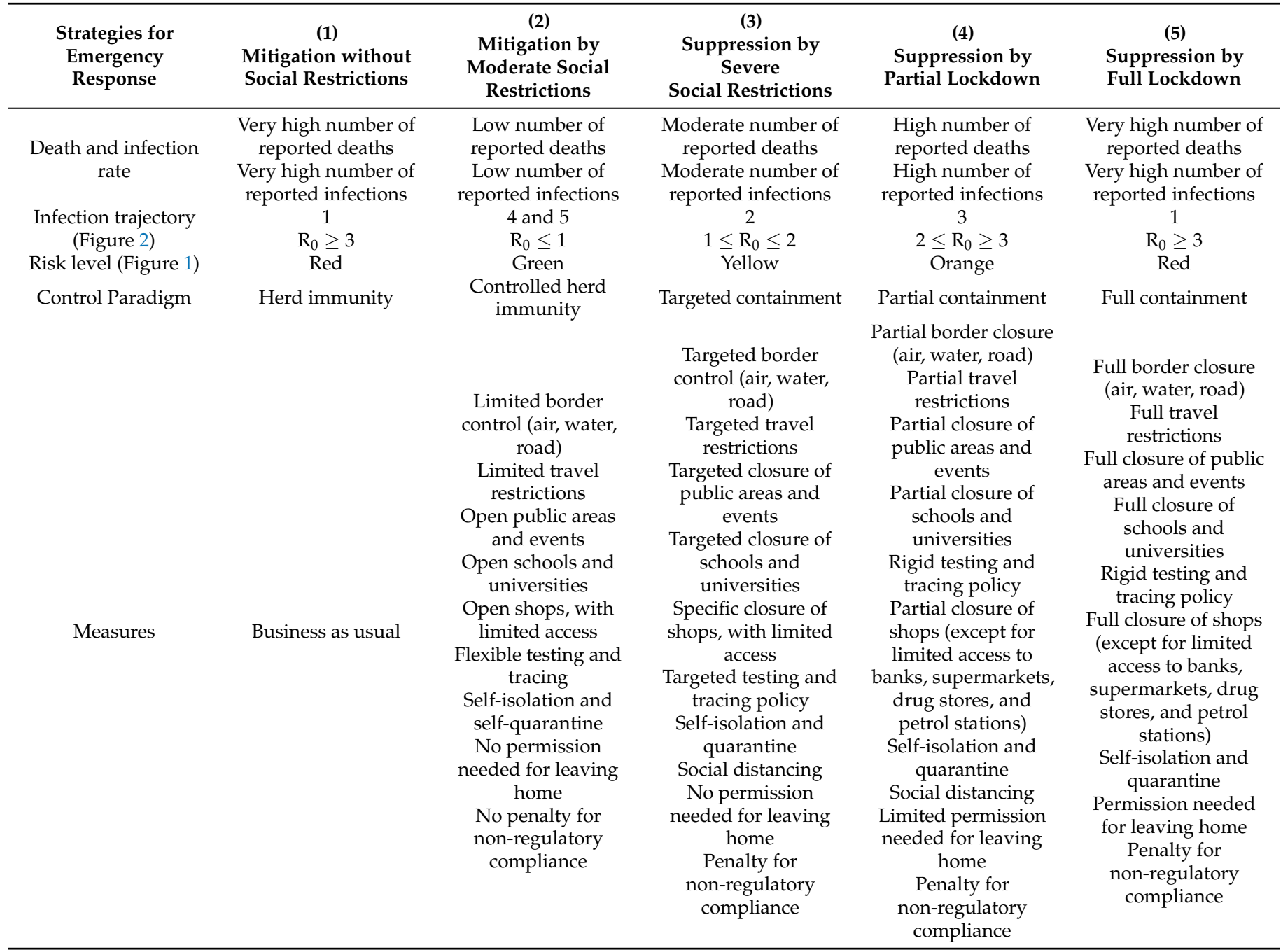


The matrix helps decision makers to identify and decide on an appropriate response strategy according to the levels of risk observed (see Table 1). In case of high case fatality and infection rate, a full lockdown suppression strategy (red band) is an extreme way to reduce the number of people diagnosed with COVID-19 and deaths. Full lockdown involves a whole country shutting down, including its vital infrastructure. This strategy may be effective in the short run, but highly undesirable in the long run as it does not prevent a resurgence of the COVID-19 outbreak, if herd immunity has not yet been established, and/or could tip a country into a deep economic recession or system collapse.

By comparison, a flexible lockdown suppression strategy (orange band) is less extreme, as a country's vital infrastructure still operates and its population is only allowed to leave their homes for buying essential food or receiving medical attention. Although a country's economy will be severely affected by a partial lockdown, it drastically reduces the number of diagnosed people and deaths.

In the case of a high case fatality rate and moderate to high infection rate (yellow band), governments can adopt a suppression strategy with various severe social restrictions, ranging from quarantine to travel regulations. For example, those who show mild symptoms associated with COVID-19 or ordinary flu and cold are to be quarantined. People working in vital sectors (e.g., transport, health care, logistics, law enforcement) are required to continue their work, while others are instructed to work remotely.

When the infection and case fatality rate decrease over the course of time, governments can decide to adopt a mitigation strategy that eases severe restrictions or replaces them with moderate restrictions (green band) ranging from social distancing or physical distancing policies. This involves control actions for limiting social contact-avoiding crowds and refraining from touching one another-intended to stop or slow down the spread of the COVID-19 disease. Finally, when the outbreak has been fully contained and no new cases of diagnosed people are reported, governments may decide to lift all restrictions so that people can continue their normal lives.

To investigate how context dependent factors and developments have co-shaped governments' choice of strategy and national infection trajectories over time, we apply the concept of tipping points commonly applied in climate change adaptation research [12-14]. Tipping points are boundary conditions under which the prevailing strategy no longer meets the clearly specified objectives, triggering a shift from one strategy to another. As illustrated in Figure 1, due to a risk reduction from $R_{0}=4$ to $R_{0}=3$, governments may wish to shift from complete lockdown to partial lockdown, but then readopt its previous strategy, if the observed risk increases (see the dashed arrow from tipping point $T_{1}$ to $T_{3}$ via $T_{2}$ ). In the context of emergency management, tipping points refer to various types of thresholds: social thresholds (herd immunity, social compliance or noncompliance with regulations), economic thresholds (governmental emergency budget deficits) and system thresholds (health care system capacity), managerial thresholds (resource pool, including nursing and law enforcement), knowledge capacity to understand the epidemiological situation) and political thresholds (political or public support for decisions and measures), all of which can be challenged by triggering events such as a substantial change in the case fatality rate and infection rate.

A country's health care system capacity, for example, can be taken as one of the key tipping points, which marks the maximum available number of intensive care unit (ICU) beds for treating severe cases. Given the exponential change in the daily number of confirmed cases determined by $R_{0}$ [15], different infection trajectories can be identified in conjunction with the tipping point (Figure 2). The first trajectory involves a steep increase in the number of confirmed cases, which exceeds the health care system capacity. A mitigation strategy without any protective measures can be pursued to obtain herd immunity. A full lockdown suppression strategy may also be considered to delay and reduce the peak of the outbreak or "flattening the curve" to contain the outbreak. The second trajectory relates to a considerable infection rate causing a temporary exceedance of the health care system capacity. A suppression strategy with severe protective measures 
(social restrictions) is required for reducing the number of confirmed cases, while forced medical rationing or triage is inevitable. The third trajectory follows a steady increase in the number of confirmed cases, causing a more persistent exceedance of the health care system capacity. This situation calls for a flexible lockdown suppression strategy including medical rationing and drastic measures) for a longer period of time, in which the health care system capacity needs to be increased. The fourth trajectory involves a slow infection rate with sufficient capacity to treat severe cases, which can be sustained through a mitigation strategy with moderate restrictions. The fifth trajectory shows a similar, though slightly faster, infection rate that can be controlled through a similar mitigation strategy to secure sufficient health care system capacity.

\section{Flattening the curve}

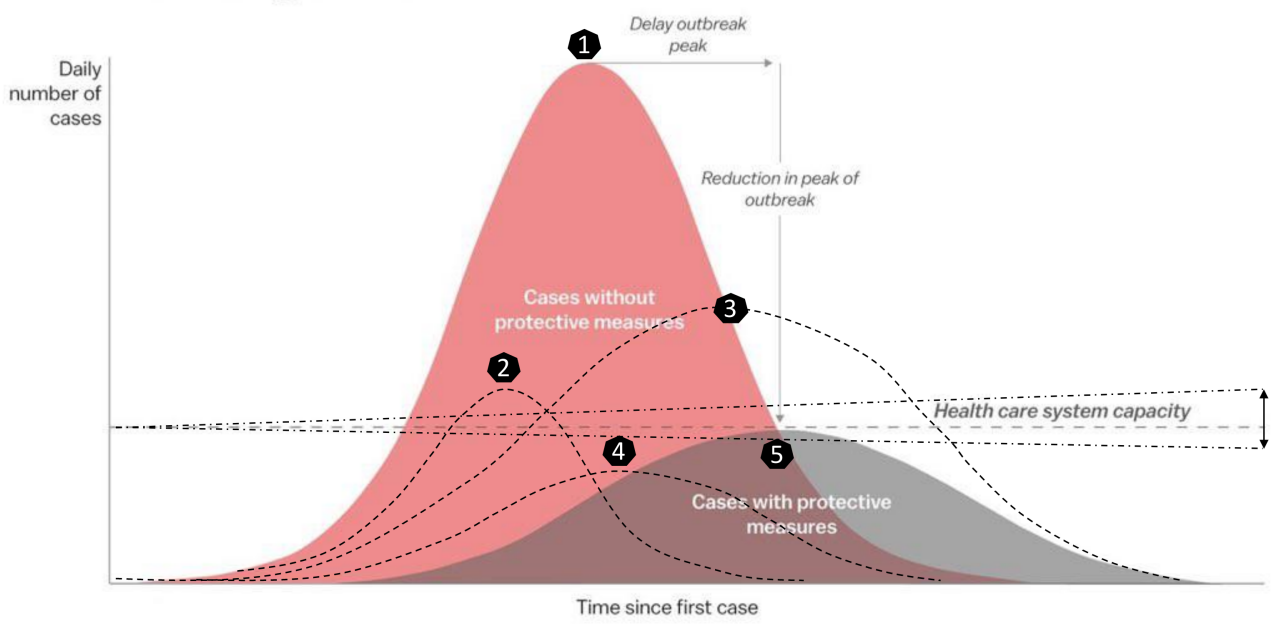

Figure 2. A static representation of infection trajectories (first created by the Control Decease Centers, Adapted by Drew Harris [16]).

It is important to note that tipping points are dynamic thresholds. The health care system capacity, for instance, may decrease over time, as health care workers can become ill or are placed under quarantine. Increasing the number of health care facilities and health care workers, including people who deliver or assist in the delivery of health services, or help operate health care facilities, improves the health care system capacity.

\subsection{Research Methodology}

\subsubsection{Case Study Selection and Case Characteristics}

A multi-case study research was conducted on Italy, France, Spain, Germany, The Netherlands, Austria, Sweden and the UK. These countries were selected on their culturally determined preference for a certain control paradigm and policy response style and categorized accordingly. Overall, in the response among western European countries, we distinguish the following policy response styles:

1. Mediterranean style: once the seriousness of the virus is recognized, drastic measures are to be taken to remedy the situation. This involves a full lockdown of (nearly) all business and public activity, a closing of the airports and borders, serious bureaucratic administration for people applying for permission to travel, active enforcement of the use of facemasks and heavy penalties for those who violate any of the above policy measures. This response style is typically reflected in the more severe suppression paradigm (see strategy 4 in Table 1) adopted by Italy, Spain and France.

2. Continental style: upon the breakout and the apparent undeniability of its severe consequences, policy instruments at the curative end of the spectrum are applied. Light or partial lockdown is announced, social distancing is encouraged, traveling is discouraged and hospital capacity stepped up to the extent possible. On the other 
hand, some flights are kept in operation, borders are kept open, people maneuver around if they wish to and fines imposed for violations are comparatively low. Germany and Austria are the most notable examples of this style, which is reflected in the modest suppression paradigm adopted by them (see strategy 3 in Table 1). There is variety in this group to the extent that Germany and Austria tend to be a bit stricter than The Netherlands, and therefore can be considered a bridge to the third and last response style.

3. Liberal style: in spite of the fact that infection and even death rates in surrounding countries begin their remarkable increase, national and local authorities worry little and brush aside the urge to act. Belief in the possible working of herd immunity is expressed and the idea that the national population is used as a medical testbed for the virus is not found to be an objectionable idea. In the UK and The Netherlands, this idea was firmly expressed and later revoked by the government upon public outcry, although policies remained remarkably carefree until a (comparatively) light lockdown became unavoidable. Sweden was the most extreme case in point, with no lockdown announced at any point, soft advice issued by the public authorities to citizens to "act responsibly" and overwhelming national pride in the government and the population at large for being more tolerant and relaxed than the rest of Europe and incurring less damage. When, further down the road, no other European countries seemed to comprehend and respect the Swedish position, active diplomatic action was undertaken to clarify the approach to neighbors. The style of the UK and The Netherlands resonates with the modest mitigation paradigm (see strategy 2 in Table 1), whereas the Swedish style corresponds to the severe mitigation paradigm (see strategy 1 in Table 1).

To a large extent, the policy response style across Europe reflects cultural value systems characterizing the relationship governments have with their citizens. Among other cultural anthropologists, Hofstede et al. [17] distinguish a number of cultural dimensions, two of which are particularly relevant here, e.g., power distance and uncertainty avoidance. Countries with higher scores for power distance favor tough and determined government action leading to severe measures. Members of the Mediterranean group represent the most notable examples of this phenomenon. Inactive governments are seen as failing to act and therefore incompetent. Countries with lower scores on power distance would have governments enact policies leaving as much responsibility to individuals as possible. That aspect is mostly strongly reflected in Germany, Austria, the UK, The Netherlands and Sweden in our case study selection. Finally, countries with high scores on uncertainty avoidance tend to respond to new unknown situations with deploying strong rule-based regulatory systems which offer mental security, effective or not. Both Mediterranean nations (France, Italy, and Spain) and continental European ones (Germany and Austria) have comparatively high scores on the uncertainty avoidance index. This must have had an impact on the cultural forces driving government and citizen behavior. Liberal countries (the UK, The Netherlands and Sweden) take more liberal stances when it comes to handling feelings of insecurity, allow for a more flexible trade-off between various societal interests and are open to a certain amount of experimentation in times of uncertainty.

Table 2 shows some characteristics of the selected countries. The countries show a combination of common characteristics and diversity on other criteria, which can be accounted for with a multiple case study design. Common characteristics also include the absence of (i) previous immunity and (ii) effective cure or vaccine. 
Table 2. Characteristics of the selected countries.

\begin{tabular}{|c|c|c|c|c|c|c|c|c|}
\hline Country & Italy & Spain & France & $\begin{array}{l}\text { The Nether- } \\
\text { lands }\end{array}$ & Germany & UK & Austria & Sweden \\
\hline \multicolumn{9}{|c|}{ Short-term coping capacity } \\
\hline Total ICU capacity & $\begin{array}{c}5.200 \\
{[18]}\end{array}$ & $\begin{array}{c}4.575 \\
{[19]}\end{array}$ & $\begin{array}{c}4.934 \\
{[20]}\end{array}$ & $\begin{array}{l}1.050 \\
{[21]}\end{array}$ & $\begin{array}{c}28.000 \\
{[22]}\end{array}$ & $\begin{array}{c}4.123 \\
{[23]}\end{array}$ & $\begin{array}{c}2.547 \\
{[24]}\end{array}$ & $526[25]$ \\
\hline $\begin{array}{l}\text { Weekly testing rate [per } \\
100.000][26]^{1}\end{array}$ & 33.89 (wk9) & $0.019(w k 5)$ & 4.95 (wk9) & $98.83($ wk11) & $\begin{array}{r}153.53 \\
(w k 11)\end{array}$ & $\begin{array}{l}102.29 \\
(w k 14)\end{array}$ & $139.29($ wk15) & $0.11(w k 4)$ \\
\hline \multicolumn{9}{|c|}{ Long-term coping capacity } \\
\hline $\begin{array}{l}\text { Gross Domestic Product } \\
\text { (current \$) [27] }\end{array}$ & $2.001 \times 10^{12}$ & $1.394 \times 10^{12}$ & $2.716 \times 10^{12}$ & $909.07 \times 10^{9}$ & $3.85 \times 10^{12}$ & $2.827 \times 10^{12}$ & $446.315 \times 10^{9}$ & $530.83 \times 10^{9}$ \\
\hline GDP growth (annual \%) [28] & 0.3 & 2.0 & 1.5 & 1.8 & 0.6 & 1.4 & 1.6 & 1.2 \\
\hline $\begin{array}{c}\text { Current health expenditure [\% } \\
\text { of GDP] [29] }\end{array}$ & 8.84 & 8.87 & 11.31 & 10.1 & 11.25 & 9.63 & 10.4 & 11.02 \\
\hline \multicolumn{9}{|c|}{ Social vulnerability } \\
\hline Population size [30] & $60.3 \times 10^{6}$ & $47.1 \times 10^{6}$ & $67.1 \times 10^{6}$ & $17.3 \times 10^{6}$ & $83.13 \times 10^{6}$ & $66.83 \times 10^{6}$ & $8.87 \times 10^{6}$ & $1.8 \times 10^{6}$ \\
\hline $\begin{array}{l}\text { Population age } 65 \text { and above } \\
\text { [\% of total population] [31] }\end{array}$ & 23 & 20 & 20 & 20 & 22 & 19 & 19 & 20 \\
\hline $\begin{array}{l}\text { Population density } \\
\left.\text { [people } / \mathrm{km}^{2}\right][32]\end{array}$ & 205 & 94 & 122 & 511 & 237 & 275 & 170 & 25 \\
\hline $\begin{array}{l}\text { Urban population [\% of total } \\
\text { population] [33] }\end{array}$ & 71 & 81 & 81 & 92 & 77 & 84 & 59 & 88 \\
\hline
\end{tabular}

${ }^{1}$ Based on the available data the weekly testing rate varies per country provided by the European Centre for Disease Prevention and Control.

As described in Table 2, diversity is present through (i) ICU capacity, (ii) testing capacity at the start of the outbreak, (iii) current health expenditure, (iv) population size, (v) population density, and (vi) demographics. A country's ICU capacity and testing capacity and the current health expenditure per capita are taken as a proxy for its coping capacity to deal with the COVID-19 outbreak in the short run. Both capacities indicate how much people can be hospitalized or tested.

Furthermore, a country's Gross Domestic Product (GDP), GDP growth and Current Health Expenditure are used as a proxy for its coping capacity to deal with the COVID-19 outbreak in the long run. These economic indicators a country's ability to upscale the short-term coping capacities in the long run.

A country's population size, population distribution (people at age 65 and older), and population density, and population in the largest city (\% of urban population) is taken as a proxy for its social vulnerability to COVID-19. Countries with a large population size combined with a large proportion of senior citizens (65 years and older) find themselves more at risk. The same applies for countries with a high population density combined with a large urban population, which allow for COVID-19 hotspots to arise in the absence of appropriate intervention.

\subsubsection{Data Analysis and Sources}

In this multi-case study research, we reviewed the emergency response strategies pursued in Italy, France, Spain, The Netherlands, Germany, Austria, Sweden and the UK. We focused on how context-dependent factors and developments have co-shaped governments' choice of strategy and national infection trajectories over time. For each country, we investigated changes in the governments' choice of strategy. Based on available data, we identified empirical relationships between the policy changes and the perceived risk of the COVID-19 pandemic. The outcome of the empirical analysis for each country is constrained by the data sources used. This means that other relationships can be found beyond our data sources.

This research aims to describe a chain of events as opposed to a narrative analysis, which is to produce rich narratives in the participants' own voices [34]. A descriptive case study analysis of causal events may present a series of themes and (sub)categories, possibly resulting in quantitative counts or statistical comparisons [35]. Such an analysis allows a researcher to focus not only on the content of participants' stories, but also on the way they are told [36]. In line with Van der Voorn [37], we describe a time-dependent sequence of causal events tied together by a tipping point. A descriptive case helps us to identify unfolding processes and study event sequences, timing and conjunctures [38]. The timeline 
for each narrative is set by the date when first cases of the individual country's epidemic was confirmed until a country's lockdown.

A triangulated research approach is applied for the construction of each causal narrative, allowing multiple research methods and data to be used and combined to improve our understanding of the same phenomenon under study (i.e., strategy development) [39]. Triangulation enables us to gather and combine data at different times (e.g., phase of the COVID-19 outbreak) and decision-making settings, involving a variety of stakeholders [40]. Triangulation relates to the various types of data that were used for the data analyses and collected from various primary and secondary sources. Primary data sources include online national and international databases of public authorities such as public health authorities and census bureaus. Secondary data sources include news sites (e.g., BBC), newspaper (e.g., LeMonde), websites, online databases and online COVID-19 trackers (e.g., OurWorld in Data) and monitoring database.

\section{Results}

\subsection{Italy}

Italy had become the second worst-hit country after China, and Italian authorities fought to contain the virus. The first two cases were confirmed in Italy on 31 January 2020, when two Chinese tourists in Rome tested positive for the virus [41]. In the following week, a third case was confirmed. It concerned an Italian man, who traveled back to Italy from the city of Wuhan, China and had to be hospitalized, [42]. On 31 January, the Italian government banned all flights to and from China, followed by a state of emergency.

On 21 February, 11 municipalities in the north of Italy were designated as the centers of the two main Italian clusters and were put into quarantine. Another cluster of cases was later detected, starting with 16 confirmed cases in the Lombardy region of Italy on 21 February [43], followed by 60 additional cases and the first deaths on 22 February [44]. In the following week, Lombardy witnessed a very rapid increase in the number of cases. The majority of positive cases in other regions could be traced to these two clusters [45]. On 6 March, the Italian College of Anaesthesia, Analgesia, Resuscitation and Intensive Care published medical ethics recommendations for triage protocols, which seemed appropriate for employment [46]. On 8 March, Prime Minister Giuseppe Conte extended the quarantine to all of Lombardy, including 14 other northern provinces. On the following day, the whole country was put in quarantine; a total of more than 60 million people $[47,48]$. In Italy, there were approximately 5200 beds in intensive care units, and 1028 of those had already been devoted to COVID-19 patients as of 11 March and the health care system was expected to reach its maximum capacity by 14 March, as predicted by the Ministry of Health on 8 March [18].

On 10 March, Italy imposed a nationwide lockdown on 60 million people and restrictions on movement; exceptions were allowed only for professional needs, primary needs and health issues. On that day, nearly all commercial activities were prohibited, but an exception was made for supermarkets and pharmacies [49]. Cinemas, theatres and gyms were also closed until 3 April. All educational centers were ordered to close, rushing 10,000 student doctors into service, scrapping their final exams. No large public events were allowed, and particularly large gatherings were forbidden. Professional sports events, including Serie A football matches, were suspended.

Between 1 March and 11 March, the percentage of patients in intensive care reported daily in Italy had consistently been between $9 \%$ and $11 \%$ of patients who were actively infected. The number of patients infected since 21 February in Italy closely followed an exponential trend. If this trend was to continue for another week, there would have been 30,000 infected patients. ICUs would then be at maximum capacity, as up to 4000 hospital beds will be needed by mid-April [18].

On 16 March, the Italian government passed a bill earmarking a EUR 25 billion stimulus package, with measures ranging from financial aid for troubling businesses to suspending tax payments for families. On $17 \mathrm{March}$, Prime Minister Conte also urged EU 
leaders to take extraordinary measures and to consider issuing a joint debt at EU level for the sake of Europe's economy to recover from the pandemic. On 21 March, the Italian government closed all non-essential businesses and industries, and further restricted the movement of people [50].

After the peak on 21 March, when 6557 new cases were reported, the number of new cases reported on daily basis seemed to be decreasing. This trend resulted from control measures (stay-at-home restrictions), which were implemented two weeks earlier, first in northern Italy (8 March) and then in the whole country (10 March). Some health care facilities in northern Italy reported that intensive care capacity had been exceeded due to the high volume of patients requiring ventilation. On 24 March, the government approved stiffer sanctions for breaking lockdown rules. The number of confirmed infections seemed to have slowly decreased in the country, with new 3612 cases reported on $25 \mathrm{March}$. The death toll rose to 7503, while the number of total confirmed infections reached 74,386 since the beginning of the crisis. Addressing the Parliament on that day, the Prime Minster made an appeal for responsibility in this "unprecedented emergency for Europe and the whole world". "Will we be up to it? History will judge us the time for assessing what we've been doing will come," he said. Conte added that it is "imperative to ensure the highest possible degree of liquidity for businesses," and that "the most valuable assets of our country must be protected by every means" [51]. As of 26 March 2020, there were 80,539 cases of COVID-19 registered in Italy. Italy had imposed a nationwide lockdown until 3 April. By 26 March, Italy had conducted 361,060 tests for the virus [52].

\subsection{Spain}

On 31 January 2020, the first COVID-19 case was confirmed in La Gomera, the Spanish Canary Islands. A tourist from Germany tested positive and was hospitalized at the University Hospital of the Nuestra Señora de Candelaria [53]. On 9 February, the second confirmed case involved a British male tourist in Palma de Mallorca. He contracted COVID19 due to close contact with a person in France who subsequently tested positive [54]. On 24 February, a medical doctor from Lombardy, who was on holiday in Tenerife, tested positive at the University Hospital of the Nuestra Señora de Candelaria in Spain [55]. Consequently, the H10 Costa Adeje Palace in Tenerife was placed in lockdown [56]. By 2 March, the number of confirmed infections in Spain crossed the 115 mark.

On 12 March, the Spanish government passed a series of tax breaks representing a EUR 14 billion stimulus package for the economy [57]. Prime Minister Sánchez also pledged EUR 3.8 billion to increase health care capacity. Madrid's museums and archives were ordered to close as of 12 March. Marital visits in prisons located in affected areas were cancelled. Spain's Muslim community suspended collective prayer services until further notice.

Spain had gone into a state of alarm since the government put the country into lockdown and declared a state of emergency on 14 March, ordering the population to self-isolate at home and to abide by social distancing measures to contain the spread of the virus. It then imposed a travel ban on 46 million people and restrictions on movement, with exceptions only allowed for professional needs, primary needs and health issues. Under the state of emergency, borders would only be open to Spanish nationals, residents and crossborder workers until the emergency ended, as announced by the Interior Minister Fernando Grande Marlaska. All shops, bars and restaurants were closed, but supermarkets and pharmacies remained open. The price of drugs and medical supplies could be capped, if needed. Private health care providers and infrastructure were temporarily taken over in the interest of the national health care system. The government also mobilized retired doctors, all final-year medical students and physicians who had not yet completed their specialty. The government decreed that all people in self-isolation would receive sick-leave benefits.

By decree of Prime Minister Sánchez on 12 March, all Spain's regional governments ordered schools and universities to be closed [58]. Some 9.5 million students were sent home for the next two weeks. The national government was criticized for not calling off the 
International Women's March in Madrid on the Sunday, which tens of thousands attended. Since then, all large events hosting more than a thousand participants were cancelled, including Valencia's Fallas Festival, which had not been cancelled since the Spanish Civil War. All sporting events were to be held behind closed doors. The Spanish soccer league was put on hold. Civil service exams were postponed until further notice. Despite political pressure from Madrid, the regional government of Andalucía refused to cancel the Holy Week festivities, which generally have hundreds of thousands of attendances every year.

On 17 March, the government approved a financial fund worth EUR 200 billion, which corresponds to about $20 \%$ of Spain's annual GDP, to help ease the negative impact of the crisis on the country's economy [59]. As of this date, Spain had a total of 11,178 COVID-19 cases (1987 more than the day before) and 491 deaths, according to Spain's Ministry of Health [60].

Prime Minister Pedro Sanchez encouraged his fellow citizens on 21 March to remain strong in the face of the COVID-19 pandemic as health authorities said that the fatality rate among Spaniards infected with COVID-19 stood at 5\% [61]. On 22 March, Sánchez announced that the "state of emergency" would be extended for another two weeks. With a majority of votes in favor (321), 28 abstentions and none against, the Spanish parliament approved the Prime Minister's plan to extend the 'state of alarm' until 11 April as Spain had become the second-deadliest European hotspot for COVID-19 after Italy [61]. With 47,160 confirmed cases, Spain's fatality rate was about $7.2 \%$. The head of the country's emergency health department said that "if we are not already at the peak, then we are close" [62]. Spain started to distribute rapid testing kits on 23 March in a desperate attempt to accelerate diagnoses in the most exposed and vulnerable sectors of society, as the number of COVID19 cases continued to rise. Nevertheless, medical personnel demanded action after Spain reported its sharpest daily increase in COVID-19 cases on 24 March and claimed about $14 \%$ of the nearly 40,000 infections were among health workers [63]. On 25 March, Spain's Health Minister, Salvador Illa, said that health equipment valued at EUR 432 million had been purchased, including 550 million masks, 950 ventilators, 5.5 million quick testing kits and 11 million gloves [64]. As of 26 March, there were 56,197 cases of COVID-19 registered in Spain [65].

By 28 March, Madrid had become the worst-hit region by COVID-19 and was close to having all of its 1500 ICU beds occupied by patients [19]. Madrid accounted for 1404 ICU patients, which is $30.6 \%$ of the national total of 4575 [19]. On this date, the Prime Minister put the whole Spanish population into lockdown, excluding those who were working in essential sectors, in an attempt to halt the spread of COVID-19 and to reduce the congestion of the country's ICUs [66]. At an extraordinary cabinet meeting on 29 March, a consensus was reached on the self-quarantine of non-essential workers for the following two weeks, from 30 March until Thursday 9 April [66]. Although this new plan was on its way to being approved, opposition parties supported the stricter measures, but criticized the government for its clumsy response to the crisis.

\subsection{France}

On 24 January 2020, the first COVID-19 case in both Europe and France was confirmed in Bordeaux. This case involved a 48-year-old French citizen who arrived in France from China. Two additional cases were confirmed by the end of the day, involving individuals who recently returned from China [67]. On 14 February, the first death from COVID-19 was reported in both Europe and France, when a Chinese tourist died after being hospitalized in Paris on 28 January. It marked the first death reported in a non-Asian country [68]. Between 10 January and 24 January, nine possible cases were identified in France; among them, three cases were confirmed with COVID-19.

In March, France had one of the highest number of COVID-19 cases in Europe. On 3 March, the Director General of Health, Professor Jérôme Salomon, said France was moving "inevitably towards stage three" of COVID-19-meaning a full-blown epidemic —as 16 deaths and almost 1000 cases were confirmed [69]. By then, France was in its second 
stage of its action plan, focusing on detecting cases and trying to contain COVID-19. The Ministry of Health announced on 12 March that non-essential surgical operations would be suspended, giving priority to of critically affected COVID-19 patients. People repatriated from COVID-19 hotspots, including China, Iran, the northern regions of Italy, Singapore and South Korea, were put in quarantine.

Some studies showed that, even in the best case scenario, the French health care system would be overwhelmed rapidly. Massonnaud, Roux and Crépey [20], for example, estimated up to 14 April the daily number of COVID-19 cases, hospitalizations and deaths, the needs in ICU beds per region and the date that ICU capacity limits would be reached in three different scenarios $\left(R_{0}=1.5, R_{0}=2.25, R_{0}=3\right)$. At the national level, Massonnaud, Roux and Crépey [20] expected the total number of infected cases to range from 22,872 in the best case $\left(R_{0}=1.5\right)$ to 161,832 in the worst case $\left(R_{0}=3\right)$, while the total number of deaths would vary from 1021 to 11,032, respectively. At the regional level, all ICU capacities may have been overrun in the worst scenario. Only seven regions may have lacked ICU beds in the mild scenario $\left(R_{0}=2.25\right)$ and only one in the best case. In all three scenarios, Corsica would have been the first region to see its ICU capacities overrun. The two other regions whose capacity would be overrun shortly after were Grand-Est and Bourgogne-FrancheComté. The study confirmed the positive impact of drastic social distancing measures, but a massive reorganization leading to an expansion of French ICU capacities seemed to be necessary to manage the coming wave of critically affected COVID-19 patients.

In his address to the nation on 12 March, French President Macron pleaded for tighter containment rules, alarmingly announcing that "we are at war" with COVID-19 which meant that the mobilization of the government and the entire nation were required [70]. He declared that public transport would not be shut down, because this would prevent medical professionals from taking care of the sick. Air France deferred flights to and from Italy for the period of 14 March and 3 April, according to AFP. President Macron ordered the shutdown of schools, universities and crèches from the Monday until further notice. All shops, bars and restaurants were closed, but supermarkets and pharmacies remained open. Large events of more than 1000 people had been banned since 8 March, except for events that were considered essential to the life of the nation. Major events such as the Paris marathon, a Six Nations rugby match, concerts and a book fair were cancelled. On 13 March, the French Prime Minister prohibited events of more than 100 people, excluding public transportation from this ban [71]. The next day, he ordered the closure of all nonessential public places, including restaurants, cafés, cinemas, and discothèques. By 17 March at midday, France declared a 15-day lockdown, which immediately went into effect.

Following the decree of an initial 15-day containment phase nationwide, an economic stimulus package was presented by French Economy Minister Bruno Le Maire on 17 March. The government pledged to help companies by granting them a delay in tax and social payments. The newly presented government plan included a EUR 345 billion injection to the economy [72]. While EUR 45 billion would allow companies to cancel or defer social security contributions, EUR 300 billion was allocated to secure bank loans to avoid any risk of bankruptcy, particularly of small and medium-sized enterprises. France imposed controls on the exports of protective gear, such as masks and gloves. The prices of hand sanitizers were regulated by the government, who took control of the production of face masks. All visits to residential care facilities for elderly people and long-term care units were suspended until further notice.

As of 17 March, French health authorities had scaled up measures to test the population for COVID-19, with 7730 cases and 175 deaths confirmed. The daily capacity to test patients for the coronavirus has gone from 2000 to 2500 was announced by the France's Ministry of Health [73]. Confronted with a growing demand for tests in the midst of the pandemic, the Health Minister Olivier Veran stated that it would not possible to screen everyone with symptoms at this stage and he compiled a priority list of people who had to be tested systematically. He announced that this list included "Those who have serious symptoms coherent with COVID-19, those ill patients who are fragile or at risk who present symptoms, 
and the first three people with symptoms who live in a home for elderly or fragile people, in order to stop the virus spreading to other residents". Additionally, "All people in hospital who show symptoms and medical staff members will also be considered a priority" [73].

On 23 March, Prime Minister Edouard Philippe announced stronger confinement rules, accompanied by sanctions for non-compliance with these measures [70]. With an increasing number of death cases, it was quite likely that the government would extend its initial containment period set to end on 31 March, according to a government spokesperson. The government would decide once it received the advisory opinion from the scientific committee, which was expected on 24 March.

With "difficult days ahead", as Prime Minister Edouard Philippe argued, and with the French army transferring patients from eastern to western France to relieve overcrowding [70], the Prime Minister declared on 27 March that the lockdown would be extended to 15 April. However, the Scientific Council of the government favored a six-week extension of the lockdown over the initial two weeks from the day of its implementation on 17 March in order to extend containment. The recommendation of the Council had been adopted by the government. The Council members reported that "Containment is currently the only really operational strategy, the alternative of a policy of large-scale screening and isolation of those detected not being feasible for the time being on a national scale" [70].

\subsection{The Netherlands}

On 27 February 2020, the first COVID-19 case was confirmed in Tilburg, The Netherlands. It involved a 56-year-old Dutchman who came back in The Netherlands from Italy. The first death was confirmed on 6 March, when an 86-year-old patient deceased in Rotterdam. On 9 March, the government requested people stop shaking hands, which appeared to be measure quickly forgotten by Prime Minister Mark Rutte who immediately then shook the hand of a health expert next to him [74]. Although 321 cases had been reported up until this date, no substantial public measures had been put in place to limit the spread of the virus. On 10 March, measures were tightened in the province of North Brabant. The State Secretary for Economic Affairs announced on 11 March that the government would offer support to entrepreneurs who found themselves in financial difficulties. The government decided to act as a guarantor for small businesses no longer able to pay off their debts. A COVID-19 help desk was launched for entrepreneurs.

On 12 March, the government banned all events of more than 100 participants until June 2020. Locations frequently visited by more than 100 people, including museums and theatres, were closed. On 12 March, the Dutch government advised people to stay at home and avoid social contact if they showed any symptoms associated with the virus. The government ordered everyone to work remotely as much as possible. Meanwhile, The Netherlands closed borders for non-nationals. Some airlines cancelled flights to and from Italy, China and other European destinations. The Dutch suspended Ministry advised people not to travel to Italy except for essential travels. Dutch airlines KLM and Transavia cancelled flights from Amsterdam to Italy.

On 15 March, the Dutch government had taken additional COVID-19 measures to last until 6 April. As of this day, The Dutch Public Health Service estimated 6000 confirmed infections. People with mild complaints had not been tested anymore since 12 March. Meanwhile, stricter measures were taken to control the outbreak. Kindergartens, schools and universities were closed until 6 April. Primary and secondary schools remained open, despite pressure from principals to close. Universities were asked to only provide classes for more than 100 students. All bars and restaurants were closed. There were restrictions for shops. As of 13 March, the estimated reproduction number was 3.25 [10].

On 16 March, the Prime Minister cautioned in a televised address to the nation that most people would contract COVID-19, but he ruled out a full lockdown as in other European countries. He said, "If someone in your family is ill, everyone should stay home. In other situations, if you want to get a bit of fresh air, you can, but go alone". He also said his government was aiming towards "herd immunity" while waiting for a vaccine, allowing 
the least vulnerable people catch the virus, while protecting the elderly and sick. A package of economic measures was already announced by the government on 17 March and included temporary arrangements for wage compensation and support for entrepreneurs. Temporary travel restrictions for entry into The Netherlands applied as of 6 pm on 19 March. As of 20 March, 2994 patients tested positive for COVID-19, 106 of which died, according to the Ministry of Health. The largest group of these (725) worked in the health care sector.

On 23 March, the Dutch government put a ban on all organized gatherings with more than three people until 1 June and granted emergency powers to mayors to ensure social distancing of $1.5 \mathrm{~m}$ between people, which Justice Minister reported to a press conference on the Monday evening. The fines could mount up to EUR 400 per person, and businesses that violated the ban risked a penalty of EUR 4000 and possible closure [75]. The government also introduced a temporary, more flexible scheme to support independent businesses, including self-employed persons securing an additional income support for living costs for a period of 3 months.

On 30 March, the Dutch public health institute RIVM acknowledged that, while the effect of measures introduced in The Netherlands to slow the spread of COVID-19 were being felt, the impact was not as strong as it had hoped for. "The most positive scenarios of last week have not been realized", said Jacco Wallinga, who modeled the spread of the disease at the RIVM. "The most likely scenario now is that we will have 2500 patients in intensive care mid-April. That is a major shift when compared with last week", Wallinga said [76]. The RIVM had hoped that 1000 intensive care beds would be filled with CIVID-19 patients by 1 April, but that total was almost reached on the Sunday. However, officials such as Diederik Gommers of the Dutch intensive care association NVIC expected to need 1600 IC beds in use by then, 1100 for COVID-19 sufferers and 500 for other patients [76]. Normal capacity is around 1150 [77]. "For us, a delayed peak in the occupancy of ICU beds is convenient, as to deliver ordered medical supplies in time", said Gommers, who acknowledged that "We buy time" [78]. The reason was partly because patients were spending an average of 23 days in intensive care, not 10 as was assumed earlier, leading to beds being occupied for a longer period of time.

On 31 March, Dutch ministers, health experts and other officials were caught in a debate on how long The Netherlands had to extend what Prime Minister Mark Rutte had described as an "intelligent lockdown" in the country's bid to control COVID-19 [79]. The current measures were due to expire on 6 April, apart from the ban on organized events, which was due to run until 1 June. Among the scientists of the Outbreak Management Team, including those of the RVIM, it was acknowledged that the reproduction number $\mathrm{R}_{0}$ had decreased below 1. However, RVIM Director, Jaap van Dissel, acknowledged a slow of the outbreak on $25 \mathrm{March}$, and the team confirmed his statement [80].

\subsection{Germany}

On 27 January 2020, the first COVID-19 case was confirmed and surfaced near Munich, Bavaria. The majority of the COVID-19 cases reported in January and early February originated from the headquarters of a car parts manufacturer in the region. Later, new clusters were caused by travelers from Italy, China and Iran, from which passenger flights were stopped on 18 March. On 25 and 26 February, in the aftermath of the COVID-19 outbreak in Italy, multiple cases connected to the Italian outbreak were confirmed in BadenWürttemberg. Additional cases, without a direct connection to the Italian clusters, were confirmed in multiple regions including Baden-Württemberg, North Rhine-Westphalia and Rhineland-Palatinate. A cluster formed in Heinsberg received media attention, due to its connection with the carnival in Gangelt [64]. By then, the state of North Rhine-Westphalia reported the largest number of COVID-19 cases confirmed in Germany [81].

By 28 February, Germany had one of the highest number of COVID-19 infections in Europe, second only to Italy [82]. Heinsberg extended closure of daycare facilities and schools to 6 March. A 14-day home isolation was mandatory for people who had been 
in close contact with individuals in the current cases as well as people who showed flu symptoms [83]. At the same time, Germany prescribed new health security measures to include regulations for air and sea travel, requiring passengers coming from China, South Korea, Japan, Italy and Iran to report their health status before entry.

On 1 March, the number of confirmed infections almost doubled within one day. However, The German Interior Minister expressed his optimism by expecting that a vaccine would become available by the end of 2020. The Finance Minister acknowledged that the government was preparing a stimulus package to mitigate the economic impact. On 2 March, the German Robert Koch Institute raised its threat level for Germany to moderate, whereas the European Centre for Disease Prevention and Control raised its threat level for Europe from moderate to high. The German Health Minister deemed the closure of borders and companies, ending large events and direct flights between China and Germany as unnecessary or inappropriate [84]. On $6 \mathrm{March}$, he excluded any measure leading to restrictions on travel within the European Union and spoke out against closing all schools and universities in Germany. On 8 March, the German Health Minister recommended cancelling events with more than 1000 attendees until further notice. On 9 March, the passing away of an 89-year-old woman in Essen and a 78-year-old man in Heinsberg marked the first death cases $[85,86]$. On the same day (estimated $R_{0}=3.95[10]$ ), the number of COVID-19 infections nearly doubled to more than 1200 compared to the previous few days, which put pressure on the government to act. Angela Merkel's administration announced measures to cushion the economic blow [87]. Merkel, who had hitherto publicly kept a low profile regarding the outbreak, emphasized that it was important to slow down the spread and buy time.

German disease and epidemic control is generally coordinated by the Robert Koch Institute, guided by a national pandemic plan. The current outbreaks were managed according to the first containment stage, containing the expansion of clusters [88]. The German government and several health officials claimed that the country was well prepared for the pandemic and did not see the urgency of taking additional measures to limit public freedom. Since 13 March (estimated $R_{0}=3.29$ [10]), the national pandemic plan had gone into the protection stage, with 14 of the 16 German federal states ordering school and kindergarten closures, postponed academic semesters and prohibited visits to nursing homes to protect the elderly. After two days, borders to neighboring countries were closed. On 14 March, several federal states tightened their measures to further limit public activities. For example, Berlin, Schleswig-Holstein and Saarland banned nightlife among other leisure venues. Shops in these regions witnessed a peak in demand for provisions and sanitary products [89]. On $16 \mathrm{March}$, a state of emergency for 14 days was declared in the state of Bavaria, where measures were introduced to limit public movement and to provide additional funds for medicine supplies. The Bavarian Minister President also ordered the suspension of all sport events and leisure facilities as of 17 March.

On 18 March, Germany expanded its travel restrictions to EU citizens from Italy, Switzerland, Denmark, Luxembourg and Spain, particularly those who had been arrived by flight or ship [90]. However, Germany still allowed flights from Iran and China due to bilateral agreements, in spite of the German Ministry of Transportation, which had claimed two days earlier that passenger flights from these countries should be prohibited. On the same date, the German state and federal governments announced steps to increase medical capacity as the country battled a mounting COVID-19 outbreak, planning to double intensive respiratory care and commandeer new spaces for treatment [91]. Government spokeswoman Ulrike Demmer said that"Doubling (intensive respiratory care beds) is the aim, and 16 federal states have been asked to work towards this plan" [22]. According to Health Minister Jens Spahn, Germany normally has around 25,000 intensive care beds with respiratory capacity, and the government ordered thousands of new respirators to boost that number [92].

On 20 March, Bavaria was the first state to declare a curfew, inspired by and identical to Austria, where it had been implemented four days before [93]. The federal government 
planned to postpone its decision on a nationwide curfew to 22 March as it faced fierce opposition from the German Association of Towns and Municipalities and reservations [94].

Then, on 23 March, the federal government imposed a national curfew. Germany followed the example of Austria and Bavaria, where it had been implemented seven days and three days before, respectively [95]. Individuals were only permitted to leave their homes for necessary activities including commuting to work, practicing sports or buying groceries, but not in groups of more than two people, particularly if they did not share the same household. Some schools were ordered to close in the western state of North Rhine-Westphalia, by then one of the most affected German regions. Lower Saxony in the northwest closed schools on 23 March. The states of Bavaria, North Rhine-Westphalia, Bremen, Schleswig-Holstein, Hesse and Berlin cancelled events of more than 1000 people, following a recommendation by the federal government [96]. Most big sport events had to take place without spectators. Public gatherings were limited to two people. Most shops, bars and restaurants were closed, but supermarkets and pharmacies remained open. Most kindergartens, schools and universities were closed in several regions for at least two weeks.

With 469 votes in favor, three against and 50 abstentions, the government's historic multi-billion-euro aid package was approved by the Bundestag on 25 March. The package comprised an Economic Stabilization Fund (WSF) with a budget of EUR 600 billion [97]. As part of the WSF, the government guaranteed EUR 400 billion to maintain access to capital for companies, as well as EUR 100 billion for the federal government to take a direct stake in companies if necessary. The final EUR 100 billion would make credit available from the state-owned development bank. The government signed off on a new aid package providing German companies financial relief. The government also changed the rules on short-term contracts to comfort employers. Germany's Federal Office of Civil Protection and Disaster Assistance disseminated a food stock guide, which also applied for non-COVID-19 situations, prescribing Germans to stockpile essential foods for up to 10 days [58]. It also suggested that Germans store $20 \mathrm{~L}$ of liquids per person, preferably bottled. The country was still allowing trucks to be on German highways on Sundays. Germany imposed border controls on the exports of protective gear, such as masks and gloves, with certain exceptions. Bus passengers could enter vehicles only through the back door and bus drivers were not selling tickets. Germany was also experimenting with drive-through COVID-19 testing.

\subsection{Austria}

Ischgl, one of Austria's most popular ski resorts, received international fame, when hundreds of tourists contracted COVID-19 there and brought it home with them, mostly to northern Europe and Germany, according to research by t-online [98]. The Director of the Tyrolean Regional Health Service, responded by stating that "from a medical point of view, it is unlikely that infections have occurred in Tyrol" [99]. Instead, he claimed that the Icelanders contracted the disease from another air passenger, a person returning from Italy. However, Icelandic authorities decided to take measures on 5 March, whereas Tyrol decided to continue the lively skiing activities. An increasing number of COVID-19 cases were reported in Ischgl-Konnex. Alarmed by the Icelandic decision, Norway began testing returnees from Tyrol [100]. On 8 March, out of 1198 infected, 491 had contracted the virus from Austria, mainly from Tyrol [99].

Austrians were allowed to return from Italy but had to undergo two weeks of quarantine, as announced by Chancellor Sebastian Kurz on 10 March [101]. Hospital visits were banned in most areas. Anyone arriving at the border from Italy to Austria could enter without a health certificate. Austria's Foreign Ministry recommended no travel to Italy. Transit was only permitted if no stopovers were made, with the exception of freight traffic. The communities of Tyrol, Paznautal and St Anton were placed under quarantine. Czech health care workers who commute between Austria and the Czech Republic were able to commute to Austria again, as Czech Home Affairs Minister Jan Hamacek agreed to 
open the Austrian-Czech border for people who work in health or social services after the country closed its borders in mid-March. Austria partially closed borders. Austria banned all arrivals from Italy by car, train or plane; entry was only permitted if a medical health certificate could be presented. Austria also suspended rail traffic from Switzerland and Liechtenstein, as well as air traffic from the UK, The Netherlands, Russia and Ukraine.

With an estimated effective reproduction number of 3.97 (as of 13 March), Austria imposed restrictions on movement, with exceptions allowed for professional needs, primary needs and health issues, on 15 March. Chancellor Sebastian Kurz announced social distancing measures that are mandatory for the entire country [102]. Public events were limited to five people. All shops, bars and restaurants were closed, but supermarkets and pharmacies remained open. Outdoor events with more than 500 participants were banned. For indoor events, the threshold is 100. Large sporting events such as football games could take place without spectators. Opera houses, cinemas and event halls were to close. Police had been told they could not go on holiday until the end of April.

The government increased its financial aid package from EUR 4 billion to EUR 38 billion to help businesses hit hardest by the COVID-19 crisis [103]. Since the first batch of EUR 4 billion dedicated to provide company liquidities, secure jobs, tax relief and credit guarantees to help businesses amid the crisis had been spent in a matter of days, for example, to buy medical supplies, the government also approved the allocation of EUR 38 billion to support businesses. The package was part of a governmental COVID-19 response program, which entered into force in the early Monday morning of 16 March. Following the announcement, the Finance Minister announced that there would likely be no savings made for the country's 2020 budget, as he would be pouring the bitter truth into the figures [104].

Austria's Education Ministry started to close schools in stages to prevent the spread of COVID-19, set to begin on 17 March with only older students' classes suspended, in order to avoid a complete shutdown with locked buildings. Starting from 16 March until after Easter, students aged 15 or older had to stay at home, with classes moving online. From 18 March, those aged 14 or younger still had the option to stay at home, but schools were to remain open. Teaching at universities was suspended. On 18 March, provincial governor Günther Platter finally ordered a lockdown throughout Tyrol. From then, no one was permitted to leave their homes without good reason. While the number of confirmed cases was 6001 with 42 deaths as of 26 March, the government announced a "massive" increase of 15,000 tests per day [105].

The week beginning 23 March was considered a game changer in Austria's fight against COVID-19. By then, the country counted a total of 2547 ICU places, 980 of which could be made available for COVID-19 patients; a high number in international comparisons [23]. Out of 5888 COVID-19 cases in Austria, 540 patients had to be hospitalized and another 90 required intensive care [24]. At this point, Austria's ICU capacity of 64,000 and more than 12,000 additional beds for mild COVID-19 cases were set up in recent weeks [24]. If the existing trends were to persist and the growth in cases were to be reduced to $9 \%$ per day in the medium term, Austria's ICU capacity would suffice until April 23 [24].

On 27 March, Austria's Minister for Health expected a peak of COVID-19 between midApril and mid-May [24]. Both he and Chancellor Kurz underlined that the situation was still very grim and the current measures had to be in place until circumstances improved, permitting a gradual lift of these measure safter 14 April to give way to a "new normal" until effective medication or a vaccine was found.

\subsection{United Kingdom}

On 31 January, two Chinese family members stayed at a hotel in York, one of whom studied at the University of York, marking the first confirmed cases of COVID-19 in the United Kingdom (UK). On 6 February, a third confirmed case was reported in Brighton, involving a man who had recently traveled to Singapore prior to visiting a ski resort in the 
Haute-Savoie, France. He had been the primary source of infection to six of his relatives during a stay in France, before returning to the UK on 28 January [106,107].

On 10 February, the total number of cases in the UK reached eight when four additional cases were confirmed in people who could be traced to the affected man from Brighton [108]. Earlier on this day, the Secretary of State for Health and Social Care issued the Health Protection (Coronavirus) Regulations 2020, to provide public health professionals "strengthened powers" to keep infected people, and those believed to be a possible risk of having the virus, in isolation [109]. On 27 February, the total number of confirmed cases in the UK reached 16, including the first case in Northern Ireland; a female who had traveled from the outbreak area in northern Italy and stopped in Dublin [110]. On 29 February, three additional cases were confirmed, making the total number of confirmed cases to 23, after testing 10,483 people [111].

On 2 March, the total number of UK cases reached 40, although this was revised to 39 after additional testing [112]. The next day, when the total number of confirmed cases in the UK reached 51, the UK Government launched its Coronavirus Action Plan, which described what the UK had achieved already and what it planned to do next [113]. On 3 March, the UK found itself in the delay phase of its action plan. Those with even mild symptoms are being asked to stay at home for seven days. Around the peak of the outbreak, the elderly and vulnerable were asked to self-isolate themselves for several weeks. Medical and behavioral scientists who took the lead in UK pandemic control hinted on delaying the peak of the outbreak until the summer months. However, Prime Minister Boris Johnson's scientific advisers urged the importance of not taking shut-down measures too soon, risking people's ignorance to public health advice [114].

According to the action plan, the British were advised against all travel to Hubei Province in China and against all but essential travel to the remainder of mainland China. British nationals had also been urged not to go to the South Korean cities of Daegu, Cheongdo and Gyeongsan. Similar travel advice applied for Italy. Travelers returning from affected areas in Italy were asked to self-isolate and call the NHS's non-emergency number 111 [115]. Those returning from a range of other countries had to go in quarantine only if they had developed symptoms. The government arranged a hotel near Heathrow Airport to support people who were required to self-isolate immediately, but only on a voluntary basis [116]. Schools only closed when a pupil or staff member tested positive or if someone at the school had close contact with a confirmed case. Two cases were confirmed at Oxford University and one at Bournemouth University, although the institutions remained open. Schools were told to suspended foreign trips. Furthermore, the government made efforts to avoid cancelling events, and even the Queen had been going about her duties, albeit without shaking hands.

On the 15 March, top intensive care specialists cautioned that Britain was not ready for the COVID-19 crisis, referring to the overwhelmed NHS that faced the risk of running out of protective clothing, drugs, beds and oxygen supplies [117]. During a webinar organized by the Association of Anaesthetists and watched by around 1000 medics, experts pointed out the insufficient availability of equipment or staff, to fight the crisis [117]. They predicted that a hospital with 10 COVID-19 patients would run out of the crucial sedation drug propofol within 11 days, and alfentanil-a painkiller and anesthetic-in less than $24 \mathrm{~h}$. They also warned of a national shortage of opioid fentanyl. Furthermore, an Imperial College COVID-19 Response Team Mitigation [118] published its study results on strategy scenarios (peak beds for $R_{0}=2.4$ and $R_{0}=2.2$ ) for the UK showing ICU bed requirements. For an uncontrolled epidemic, the research team predicted that ICU capacity would be exceeded as early as the second week in April, with an eventual peak in ICU or critical care bed demand over 30 times greater than the maximum supply in the UK.

On 16 March, Johnson put the UK in lockdown to contain the spread of the pandemic, abandoning his controversial "herd immunity" approach and following the approach of continental Europe. On 17 March, the government announced that GBP 330 billion would be made available in loan guarantees for businesses affected by the pandemic [119]. On 
that day, the UK death toll rose to 71, while the number of confirmed cases increased to 1950 [120]. In a press conference on 20 March, the UK Prime Minister said that the government would support the British people in a way that it never had before. He detailed the government's economic rescue plan, backed by Chancellor Rishi Sunak who called the economic intervention "unprecedented" in the history of the British state, and said that it had become one of the most "comprehensive in the world" [121]. The UK Chancellor planned for a GBP 12 billion package of public spending and tax cuts to mitigate the impact of COVID-19. The government's new package, also known as the "coronavirus job retention scheme" was designed to protect workers and their employers. The government committed itself to support pay wages, which was a primer in UK history. Johnson also said that he was strengthening the measures taken on 17 March and ordered all pubs, bars, restaurants, and cafes to close. 65,000 retired doctors and nurses were asked to return to the NHS to join forces in tackling the COVID-19 outbreak as part of a new law enacted on 19 March [122].

On 23 March, the UK Prime Minister announced a strict lockdown, giving the right to the police to enforce these measures. Downing Street confirmed Foreign Secretary Dominic Raab as the "designated survivor" to replace Prime Minister Boris Johnson if he would become incapacitated due to COVID-19 [123]. It was decided that Brexit talks were no longer held in London "in the form originally scheduled" and the two sides were looking into ways to continue discussions online. On 24 March, the UK Health Secretary announced the formation of a new 250,000-strong corps of "NHS Volunteer Responders", tasked with bringing essential supplies to the most vulnerable people being shielded at home, in a series of steps to help prevent the NHS from being overwhelmed by COVID-19 cases in the following weeks [124]. The NHS had over 4000 intensive care beds at the start of March with around four in five occupied [125]. However, since then, work had been carried out to increase supply. Due to a business deal made with the private sector, access was granted to 1200 ventilators used in their hospitals. Furthermore, the NHS planned to hospitalize COVID-19 patients in a makeshift field hospital in the ExCeL Centre in East London, known as an exhibition space, which had been used in the past for Crufts and Comic Con. This field hospital, with capacity of 4000 patients, could offer some relief [126]. The Nightingale Hospital, the temporary base, was staffed by NHS medics aided by the military and initially provided around 500 beds equipped with ventilators and oxygen [125]. In total, an extra 8000 hospital beds were made available across the country, nearly 1200 ventilators and almost 20,000 fully qualified staff were expected to become available from the following week [127].

On 26 March, the death toll increased by more than 100 in a day for the first time, rising to 578 , while a total of 11,568 tested positive for the virus [128].

\subsection{Sweden}

On 31 January 2020, the first Swedish case was confirmed in Jönköping, concerning one person who had traveled to Sweden from Wuhan, China, on the 24 of January. The case was fully isolated and there were no cases of further spread reported. With five additional cases confirmed on the 27 of February [39], the Swedish Public Health Agency stated that these cases were related to travel to high-risk zones, but ruled out any clear evidence of community transmission [40]. Disease control measures, including extensive contact tracing, took effect in over 200 travel-related cases in the following weeks, all of which connected to confirmed cases or travel to high-risk regions [41].

Many of those who had tested positive for the virus during the early stage of the outbreak in Sweden had contracted COVID-19 while on vacation in Italy during the oneweek spring break in late February [42]. During the period of the spring break, which usually takes place in different areas of Sweden, around one million Swedes had traveled abroad [43]. Initially, those who had developed symptoms after traveling from high risk areas such as China, Iran, northern Italy, Tyrol and South Korea, or with pneumonia of unknown cause, had to undergo testing. 
Subsequent studies carried out by the Swedish Public Health Agency confirmed that disease control measures such as isolation and contact tracing proved to be successful in preventing the infection to spread from Italy. The studies also rejected earlier assumptions that Swedes returning from northern Italy and Tyrol had become the primary sources of the outbreak in Sweden, because it was more likely the case that the virus had been brought to Sweden by hundreds of different people from a range of countries, because the outbreak by that time remained under the radar in many other parts of the world, and other countries were already experiencing a large spread [44]. In fact, investigation of early Swedish cases pointed out that several early cases had introduced the virus from the United Kingdom and the United States, and also from France and The Netherlands [46].

Since the start of the outbreak in Sweden, Stockholm County witnessed a significantly higher number of cases in the Stockholm region compared to other regions of Sweden, including the densely populated regions Skåne and Västra Götaland. According to the Director-General at the Public Health Agency, this was caused by the later Stockholm spring break compared to other regions [47].

On 6 March, the first cases of community transmission were confirmed among two patients in Stockholm. They were assumed to have been infected through community transmission approximately seven days before seeking care. The following day, initial cases were confirmed in the counties of Jämtland and Västernorrland [50].

In suspicion of local transmission in the Stockholm area and Västra Götaland, the Swedish Public Health Agency upscaled the risk of community spread from moderate to very high on 10 March [52].

Since the COVID-19 outbreak was declared a pandemic by the WHO on 11 March, an older adult in the Stockholm region died at the ICU of Karolinska University Hospital. It was reported that the person in question contracted the virus through community transmission, which occurred about one week prior to death [55]. Following the first confirmed case in Västmanland County on 13 March, the disease manifested itself all of the 21 regions in Sweden [1]

On 13 March, the Swedish Public Health Agency declared that the containment of the COVID-19 spread had entered a new phase, as other efforts were required. The primary aim of the agency was still to delay spread among the population and to prevent the elderly and most vulnerable from contracting the disease [57]. However, contact tracing was no longer be part of the strategy, and testing efforts were concentrated on people already in hospital or those with a high-risk profile [59].

The Swedish government's overall objective in the Swedish response to the pandemic was to limit the spread of infection in the country as an attempt to avoid exceedance of Swedish health system capacity. It assured that the municipalities and regions responsible for the health care were well capacitated to cope with the pandemic [66]. The government put much faith and effort into encouraging the right behavior and creating social norms, rather than imposing mandatory restrictions. Government officials such as the Swedish Prime Minister appealed to each individual to take responsibility for their own health and the health of others, and to comply with the recommendations issued by the Public Health Agency of Sweden [67].

\subsection{Case Comparison}

The cases show that the COVID-19 pandemic started in Europe from January 2020 or later in different regions. We here compare how context-dependent factors and developments co-shaped the governments' choice of strategy and national infection trajectories over time. Italy was the first to take intervention measures, soon followed by Germany, Spain, The Netherlands, Austria and the other countries (see Figure 3). The timing and types of interventions can be explained in light of the tipping points described in Table 3. 
Table 3. A time line of national response strategies with courtesy of and adapted from Imperial College London [118].

\begin{tabular}{|c|c|c|c|c|c|}
\hline Country & Ground for Policy Response & Strategy & Type of Measure & Measure & Effective Date \\
\hline \multirow{5}{*}{ Austria } & Delaying the spread & 3 & School closure & Nationwide school closures & 14 March 2020 \\
\hline & Delaying the spread & 4 & Public events banned & Banning of gatherings of more than 5 people & 10 March 2020 \\
\hline & Increasing reproduction number $\left(\mathrm{R}_{0}>3\right)$ & 5 & Lockdown ordered & $\begin{array}{l}\text { Banning all access to public spaces and gatherings of more } \\
\text { than } 5 \text { people. Advice to maintain } 1 \mathrm{~m} \text { distance. }\end{array}$ & 16 March 2020 \\
\hline & Increasing reproduction number $\left(\mathrm{R}_{0}>3\right)$ & 5 & Social distancing encouraged & Recommendation to maintain a distance of $1 \mathrm{~m}$ & 16 March 2020 \\
\hline & Increasing reproduction number $\left(R_{0}>3\right)$ & 5 & Case-based measures & Implemented at lockdown & 16 March 2020 \\
\hline \multirow[t]{6}{*}{ The Netherlands } & Delaying the spread & 4 & School closure & Nationwide school closures & 16 March 2020 \\
\hline & Delaying the spread & 3 & Public events banned & Bans of events $>100$ people & 12 March 2020 \\
\hline & First death cases confirmed & 2 & Social distancing encouraged & No hand shaking & 9 March 2020 \\
\hline & Delaying the spread & 2 & Case-based measures & $\begin{array}{l}\text { Advice for everyone experiencing symptoms to contact a } \\
\text { health care agency to get tested and then self-isolate }\end{array}$ & 12 March 2020 \\
\hline & Following "Declaration of war" & 4 & School closure & Nationwide school closures & 14 March 2020 \\
\hline & "Declaration of war" issued & 4 & Public events banned & Bans of events $>100$ people & 13 March 2020 \\
\hline \multirow[t]{3}{*}{ France } & Increasing reproduction number $\left(R_{0}>3\right)$ & 5 & Lockdown ordered & $\begin{array}{l}\text { Everybody has to stay at home. Need a self-authorization } \\
\text { form to leave home }\end{array}$ & 17 March 2020 \\
\hline & Increasing reproduction number $\left(\mathrm{R}_{0}>3\right)$ & 5 & Social distancing encouraged & Advice at the time of lockdown & 16 March 2020 \\
\hline & Protection stage of national pandemic plan & 4 & School closure & Nationwide school closures & 14 March 2020 \\
\hline \multirow[t]{6}{*}{ Germany } & Increasing reproduction number $\left(R_{0}>3\right)$ & 5 & Public events banned & $\begin{array}{l}\text { No gatherings of }>1000 \text { people. Otherwise regional } \\
\text { restrictions only until lockdown. }\end{array}$ & 22 March 2020 \\
\hline & Increasing reproduction number $\left(\mathrm{R}_{0}>3\right)$ & 5 & Lockdown ordered & Gatherings of $>2$ people banned, $1.5 \mathrm{~m}$ distance & 22 March 2020 \\
\hline & Government assured preparedness & 3 & Social distancing encouraged & $\begin{array}{c}\text { Avoid social interaction wherever possible recommended } \\
\text { by Merkel }\end{array}$ & 12 March 2020 \\
\hline & Increased threat level by Robert Koch Institute & 3 & Case-based measures & $\begin{array}{l}\text { Advice for everyone experiencing symptoms to contact a } \\
\text { health care agency to get tested and then self-isolate }\end{array}$ & 6 March 2020 \\
\hline & Increasing reproduction number $\left(\mathrm{R}_{0}>4\right)$ & 4 & School closure & Nationwide school closures & 5 March 2020 \\
\hline & High ICU occupancy & 4 & Public events banned & The government bans all public events & 9 March 2020 \\
\hline \multirow[t]{3}{*}{ Italy } & Potential exceedance of ICU capacity & 5 & Lockdown ordered & $\begin{array}{l}\text { The government closes all public places. People have to } \\
\text { stay at home except for essential travel. }\end{array}$ & 1 March / 2020 \\
\hline & Increasing reproduction number $\left(\mathrm{R}_{0}>3\right)$ & 4 & Social distancing encouraged & $\begin{array}{l}\text { A distance of more than } 1 \mathrm{~m} \text { has to be kept and any other } \\
\text { form of alternative aggregation is to be excluded }\end{array}$ & 9 March 2020 \\
\hline & Increasing reproduction number $\left(\mathrm{R}_{0}>3\right)$ & 4 & Case-based measures & $\begin{array}{l}\text { Advice to self-isolate if experiencing symptoms and } \\
\text { quarantine if tested positive }\end{array}$ & March 2020 \\
\hline
\end{tabular}


Table 3. Cont.

\begin{tabular}{|c|c|c|c|c|c|}
\hline Country & Ground for Policy Response & Strategy & Type of Measure & Measure & Effective Date \\
\hline \multirow{4}{*}{ Spain } & Increasing reproduction number $\left(\mathrm{R}_{0}>4\right)$ & 4 & School closure & Nationwide school closures & 1 March 2020 \\
\hline & State of emergency declared & 5 & Public events banned & Banning of all public events by lockdown & 14 March 2020 \\
\hline & State of emergency declared & 5 & Lockdown ordered & Nationwide lockdown & 14 March 2020 \\
\hline & Increasing reproduction number $\left(\mathrm{R}_{0}>4\right)$ & 4 & Social distancing encouraged & $\begin{array}{c}\text { Advice on social distancing and working remotely from } \\
\text { home }\end{array}$ & 9 March 2020 \\
\hline \multirow{5}{*}{ UK } & Increasing fatality rate & 5 & Case-based measures & $\begin{array}{l}\text { Advice to self-isolate for } 7 \text { days if experiencing a cough or } \\
\text { fever symptoms }\end{array}$ & 17 March 2020 \\
\hline & Increasing reproduction number $\left(\mathrm{R}_{0}>3\right)$ & 4 & School closure & $\begin{array}{l}\text { Nationwide school closure. Childminders, nurseries and } \\
\text { sixth forms are told to follow the guidance. }\end{array}$ & 21 March 2020 \\
\hline & $\begin{array}{l}\text { Abandoning controversial herd immunity } \\
\text { approach }\end{array}$ & 5 & Public events banned & Implemented with lockdown. & 24 March 2020 \\
\hline & $\begin{array}{c}\text { Abandoning controversial herd immunity } \\
\text { approach }\end{array}$ & 5 & Lockdown ordered & $\begin{array}{l}\text { Gatherings of more than } 2 \text { people not from the same } \\
\text { household are banned and police enforceable }\end{array}$ & 24 March 2020 \\
\hline & Delay phase of action plan & 3 & Social distancing encouraged & $\begin{array}{c}\text { Advice to avoid pubs, clubs, theatres and other public } \\
\text { institutions. }\end{array}$ & 16 March 2020 \\
\hline \multirow{4}{*}{ Sweden } & Delay phase of action plan & 2 & Case-based measures & $\begin{array}{l}\text { Advice to self-isolate for } 7 \text { days if experiencing a cough or } \\
\text { fever symptoms }\end{array}$ & 12 March 2020 \\
\hline & Increasing reproduction number $\left(2<\mathrm{R}_{0}<3\right)$ & 2 & School closure & Colleges and upper secondary schools shut & 18 March 2020 \\
\hline & Focus on right behaviour and social norms & & Social distancing encouraged & $\begin{array}{l}\text { People even with mild symptoms are told to limit social } \\
\text { contact, encouragement to work from home }\end{array}$ & 16 March 2020 \\
\hline & Increased risk level—moderate to high & 1 & Case-based measures & $\begin{array}{c}\text { Advice to self-isolate if experiencing a cough or fever } \\
\text { symptoms }\end{array}$ & 10 March 2020 \\
\hline
\end{tabular}




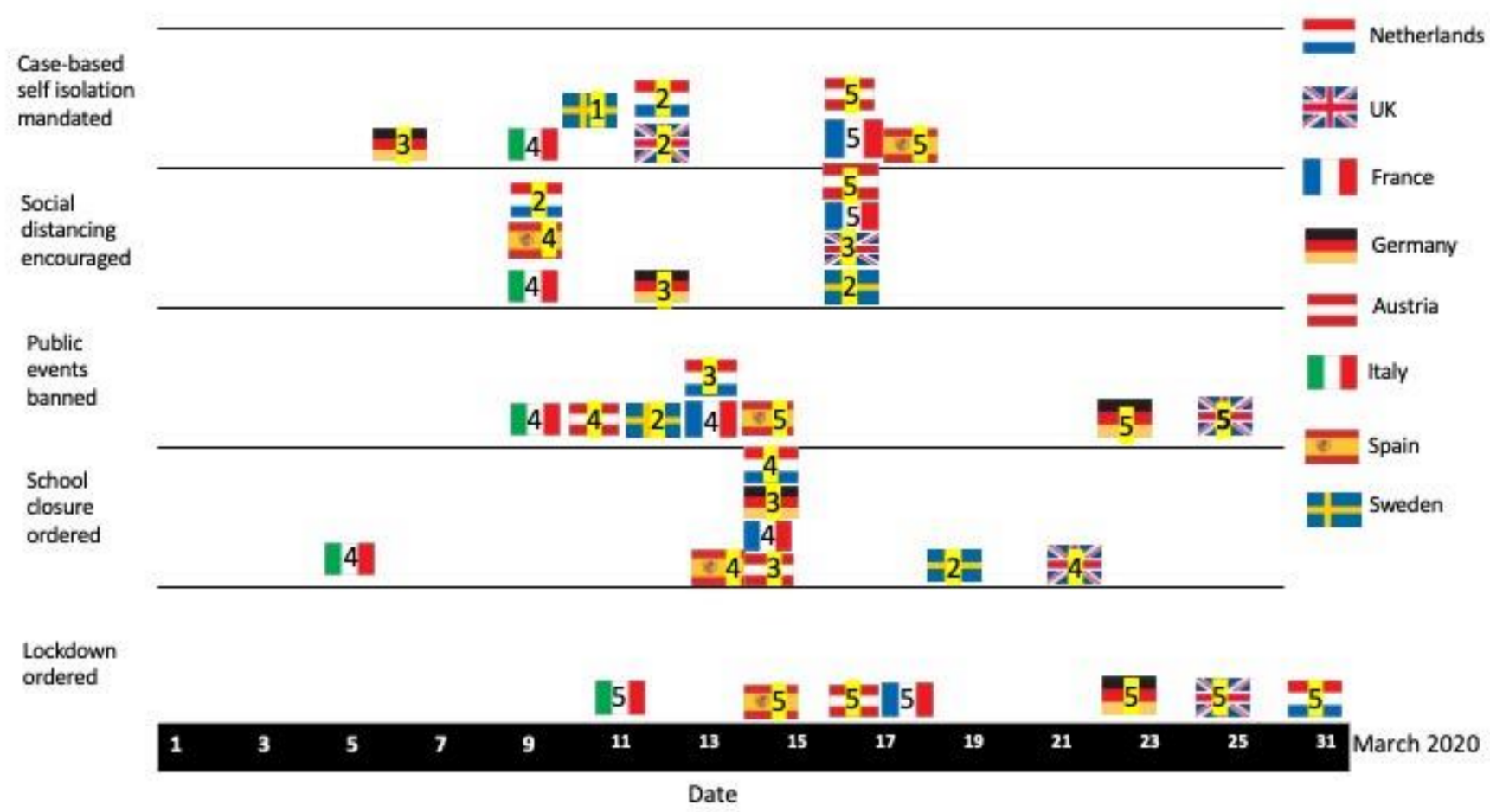

Figure 3. Time line of national responses with courtesy of and adapted from Imperial College London [118]. The numbers presented in the country flags correspond to the adopted strategy.

During the first wave of the COVID-19 outbreak, all countries adopted an initial strategy, but they switched to other strategies later on. An accumulative pattern of interventions can be observed in which these countries progressed into lockdown, albeit at varying paces and magnitudes. In Italy, Spain and France, social restrictions proved to be insufficient to successfully suppress the outbreak, as reproduction numbers remained larger than three and so full lockdown rapidly became inevitable [118]. Facing a reproduction number larger than three, Italy initially adopted a suppression strategy (strategy 4). Despite a drop in the $\mathrm{R}_{0}$, Italy rapidly switched to a suppression strategy of partial lockdown, as the daily number of infections and deaths still increased exponentially. As the ICU capacity had already been exceeded in some parts of Italy, a rapid switch to a suppression strategy of full lockdown (strategy 5) was inevitable. A similar pattern can be observed in Spain, which was able to upscale its testing policy only after its lockdown. France faced its lockdown much faster than Italy and Spain, as it anticipated a high IC admission rate and the need to upscale its ICU and testing capacities.

By comparison, Germany and Austria adopted a mitigation strategy by moderate social restrictions. In both countries, moderate social restrictions imposed by the government initially appeared to be more effective as the population abided by these restrictions, but even that could not prevent a full lockdown eventually [129,130]. Unlike Austria, Germany's medical capacity, including ICU and testing capacity, was sufficient, but it still boosted its capacity to anticipate a steep rise in IC admissions. In the German case, the transition to a full lockdown was not triggered by exceedance of the ICU and testing capacity, whereas such an exceedance was still looming for Austria, even after its full lockdown.

The Netherlands and UK initially adopted the controversial mitigation strategy with modest social restrictions (strategy 2), but were forced to change their initial strategy over the course of time. The Dutch government initially adopted a mitigation strategy, as it was believed that it could slow down the spread of the virus, while building controlled 
herd immunity. As the numbers released by the Dutch National Institute for Public Health and the Environment were not especially encouraging, the country's pragmatic balancing act did not appear to be working as intended. Consequently, it gradually shifted from a mitigation (strategies 3 and 4) to a suppression strategy of full lockdown (strategy 5). The Dutch government was constantly caught up in the balancing act of preventing an exceedance of its ICU capacity without depriving people too much of their freedom. The government also found itself in a difficult situation as the testing capacity lagged behind the increasing testing demand, despite major upscaling efforts.

The same controversial strategy of herd immunity was also initially spearheaded by the UK government, which later shifted to a suppression strategy after the public release of a technical report prepared by the Imperial College COVID-19 response team. This team concluded that a middle-of-the-road mitigation approach, which had initially been pursued by the UK, would overwhelm ICU capacity many times over.

While the COVID-19 pandemic swept through Europe, Sweden became the continent's controversial exception on how to tackle the virus. The Swedish government went for the controversial strategy of herd immunity. It sparked outrage among people concerned by a seemingly cavalier approach to the death toll and enthusiasm from those more worried about individual freedom and protecting the economy. Due to a targeted testing and tracing policy, the government's appeal to each individual to take responsibility for their own health and the health of others, Sweden's ICU capacity was never at risk and so it was able to avoid a full lockdown. The result was a fatality rate higher than Sweden's Nordic neighbors, but a smaller hit on the economy than most other European countries.

The level of social compliance with intervention measures varied between countries. As the COVID-19 pandemic progressed at an unprecedented rate and pace, sub-regions of Italy, France, The Netherlands and Spain witnessed reported health care system saturation due to very high patient loads requiring intensive care. The cases confirm that if the pandemic had expanded without any strong countermeasures and government response, countries would experience demands that far exceeded available ICU capacity. In all countries, health care staff were under pressure, and resources were strained across all countries. There have been reports of additional strain or shortages in the following areas: ventilator availability; sampling material and laboratory materials affecting diagnostic capacity for COVID-19 testing (which also affects other laboratory services); contact tracing; surveillance; risk communication; personal protective equipment; shortages of staff and space due to increased needs for triage and isolation of suspected cases.

ECDC and the World Health Organization (WHO) recommended timely and accurate COVID-19 laboratory testing as an essential part of slowing down the COVID-19 outbreak, supporting decisions on infection control strategies and patient management at health care facilities, and detecting asymptomatic cases that could spread the virus further if not isolated. In the early stages of the COVID-19 pandemic, most countries only had the capacity to test a small proportion of suspected cases and tests were reserved for severely ill patients or for high-risk groups (e.g., contacts of cases). Although some of the countries gradually adopted the WHO testing policy, these tests required well-equipped laboratory facilities and highly skilled technical experts. However, these countries faced infrastructural bottlenecks and supply shortages, limiting testing capacity below the growing demand for COVID-19 diagnostics across the EU. Therefore, countries improved access to reliable rapid diagnostic tests, in particular rapid antigen tests for COVID-19, to relieve the pressure on laboratories and to expand testing capacity to meet the most urgent medical and public health needs.

\section{Discussion}

The results show considerable variety across the country cases on strategy development for emergency responses (see Figure 3), but general patterns can be observed. The countries under study provide valuable insight into the different ways in which strategy development took place in different though related epidemiological situations. 
As a starting point for our review, we categorized the selected countries according to their culturally determined preference for policy response style (Mediterranean, continental and liberal styles), which is reflected in the initially adopted control paradigm and the associated strategy. The cases confirm that the Mediterranean countries abide by a more severe suppression strategy (strategy 4), whereas the continental and liberal countries appreciate a modest mitigation (strategies 1 and 2) or suppression (strategy 3). However, it cannot be argued that the Mediterranean countries are better off than their counterparts. Except for Sweden, all countries initially started with a modest mitigation or suppression strategy with moderate social restrictions, but they went into lockdown at varying speed. The latter can be explained by the countries' abilities to scale up ICU and testing capacities in the short term, which also requires long-term coping capacity. This suggests that tipping points are dynamic thresholds in the long run.

Secondly, the reproduction number $R_{0}$ is an important criterion for preparing emergency response strategies. Estimating reproduction numbers for COVID-19 can be challenging, due to high proportions of infections not detected by health systems and regular changes in testing policies, resulting in different proportions of infections being detected over time and between countries. Due to differences in the size and age distribution of the population in countries (see Table 2), each country has a different infection trajectory. This suggests that social vulnerability needs to be taken into account in emergency response strategies.

In addition, reproduction numbers are also important indicators for forecasting exceedance of health care system capacity thresholds. The increased pressure caused by COVID-19 on the countries' ICU capacity is dependent on the level of preparedness and surge capacity that a given country or area has implemented or can implement rapidly. If incidence increases quickly and if additional urge capacity for resources, staff and hospital beds are not ensured, the impact of COVID-19 will be very high and will likely result in considerable additional morbidity and mortality in COVID-19 cases. This impact will be mostly concentrated in vulnerable populations of the elderly and persons with chronic underlying conditions. Already stretched capacities would be further exacerbated if substantial numbers of health care workers become infected with the virus. Although the influenza season peaked in the countries under study, some health care systems may still be under pressure from residual and continued severe influenza cases.

The types of emergency response need to be conceived in light of the level of risk and uncertainty faced during the COVID-19 pandemic. In the advent of the pandemic outbreak, emergency management has to prepare an adequate response, often derived from uncertain information about the level of risk. We argue that Mediterranean countries (France, Italy and Spain), with high scores on both power distance and uncertainty avoidance, have a tendency to respond to new unknown situations by deploying strong rule-based regulatory systems which offer mental security and social order. This seems to be lesser in the case of the continental countries (Germany and Austria) with low power distance and high uncertainty avoidance, and especially in liberal countries (The Netherlands, the UK and Sweden) with low power distance and low uncertainty avoidance. Uncertainty avoidance leads to a paradoxical situation: on the one hand, it is recognized that medical experts cannot provide decisive evidence on uncertain risks, while on the other hand, decision makers appeal to medical experts for some kind of certainty. The cases show that decision makers resort to the "better safe than sorry" precautionary principle to legitimize their decisions and actions in high uncertain and risk situations.

Furthermore, due to the strong interconnectedness and interdependencies of social, economic and technical factors, it is difficult to clearly assess the uncertain impacts of emergency responses [11,131]. Risks and uncertainties may also vary-increase or decreaseover time. These countries show that mitigation and suppression strategies are feasible under specific conditions or in different phases of the outbreak, e.g., the "intelligent lockdown" in The Netherlands (see Figure 3 and Table 3). It also requires governments to have sufficient coping capacity (health care capacity, enforcement, economic resilience) 
to switch from one strategy to another if conditions change or the contemporary strategy proves to be ineffective, due to newly attained knowledge and information about the epidemiological situation.

Moreover, the COVID-19 pandemic does not stay contained in national borders [132]. This governments motivated at early stages of the outbreak to fully or partially close land borders and restrict entry of citizens from affected countries, and motivated private decision makers to disrupt trade, travel, and commerce by cancelling scheduled commercial flights and reducing shipping and cargo services. This indicates that a real-time understanding of the outbreak combined with a globally broadcasted response allows national governments to implement nationwide interventions with widespread adherence and support [133].

Finally, COVID-19 is having a major impact on both the European and global economies. Estimating the economic effects of the COVID-19 outbreak is complicated due to the many uncertainties involved. The outbreak negatively affects consumer behavior. Economic productivity decreases as people in countries subject to quarantine will have a limited possibility to work. Purchases are postponed or even cancelled (eating out, vacations). Trade has become cumbersome and more expensive. These higher costs will have the same effect as temporary non-tariff trade barriers, such as phytosanitary restrictions. Governments, therefore, prepared stimulus packages to mitigate the economic impact, including measures ranging from financial aid for troubling businesses to suspending tax payments for families. However, some economists [134] urge for careful analysis of economic consequences of current mitigation steps so that the economic trade-offs between public health and the economy can be considered quantitatively. Others claim that public health measures targeting COVID-19 and restarting the economy need to work in tandem, with a prerequisite to a sustained economic recovery being a sensible public health approach to tackling COVID-19 [9,135]. In either case, this dilemma is likely to instigate challenging debates between economists and public health experts, and between policy makers and politicians and the public.

\section{Conclusions}

This paper has applied insights from the field of disaster management and climate change adaptation, in which decision making under uncertainty is common practice, to investigate appropriate strategies for emergency response. It developed a calibrated risk matrix and typology of emergency strategies that have been developed for a systematic review of strategy development in emergency response in eight European countries: The Netherlands, Italy, France, Spain, Germany, Austria, the UK and Sweden.

Based on this evaluation, the following main conclusions are drawn: (i) countries have a culturally determined preference for policy response styles (Mediterranean, continental and liberal styles) based their relative levels of power distance and uncertainty avoidance, which (ii) are reflected in the initially adopted control paradigms and the associated strategies; and (iii) the Mediterranean countries (Italy, France, Spain) with a high level of power distance and uncertainty avoidance have a tendency to respond to new unknown situations by deploying strong rule-based regulatory systems which offer mental security and social order, whereas continental countries (Germany and Austria) with low power distance and high uncertainty avoidance, and liberal countries (The Netherlands, the UK and Sweden) with both low power distance and low uncertainty avoidance take intermediate scores or are even open to certain levels of trade-offs between various interests or even experiments.

Decision makers are recommended to recognize that national efforts at pandemic preparedness have benefits beyond national borders. New participatory processes such as risk mapping are increasingly important in the preparedness phase, making it possible to establish networks and partnerships that people can rely on during the response. Resources for development assistance should be used to provide incentives for national investments and international collaborations in such preparedness. 
Author Contributions: Conceptualization, T.v.d.V., M.d.J.; methodology, T.v.d.V., M.d.J.; validation, T.v.d.V., M.d.J.; formal analysis, T.v.d.V.; investigation, T.v.d.V.; resources, T.v.d.V.; data curation, T.v.d.V.; writing-original draft preparation, T.v.d.V.; writing-review and editing, T.v.d.V. and M.d.J.; visualization, T.v.d.V.; supervision, M.d.J.; project administration, T.v.d.V.; funding acquisition, T.v.d.V. All authors have read and agreed to the published version of the manuscript. Please turn to the CRediT taxonomy for the term explanation. Authorship must be limited to those who have contributed substantially to the work reported.

Funding: This research received no external funding.

Institutional Review Board Statement: Not applicable.

Informed Consent Statement: Not applicable.

Data Availability Statement: Publicly available datasets were analyzed in this study. This data can be found here: https:/ / www.ecdc.europa.eu/en/publications-data/covid-19-testing and https: / / data.worldbank.org/indicator/SP.POP.TOTL (acceessed on 2 February 2021).

Acknowledgments: The authors would like to acknowledge their gratitude to Prosun Bhattacharya (KTH Stockholm) and Theo Harmsen (University Medical Centre Utrecht) for providing valuable feedback on previous drafts of the manuscript and three anonymous reviewers for providing constructive feedback from which the manuscript has significantly improved. The research did not receive any specific grant from funding agencies in the public, commercial, or not-for-profit sectors.

Conflicts of Interest: The authors declare no conflict of interest.

\section{References}

1. World Health Organization. Report of the Who-China Joint Mission on Coronavirus Disease 2019 (COVID-19); World Helath Organization: Geneva, Switzerland, 2020.

2. Zhou, P.; Yang, X.-L.; Wang, X.-G.; Hu, B.; Zhang, L.; Zhang, W.; Si, H.-R.; Zhu, Y.; Li, B.; Huang, C.-L.; et al. A Pneumonia Outbreak Associated with a New Coronavirus of Probable Bat Origin. Nature 2020, 579, 270-273. [CrossRef] [PubMed]

3. Leung, K.; Wu, J.T.; Liu, D.; Leung, G. First-Wave COVID-19 Transmissibility and Severity in China Outside Hubei after Control Measures, and Second-Wave Scenario Planning: A Modelling Impact Assessment. Lancet 2020, 395, 1382-1393. [CrossRef]

4. Okell, L.C.; Verity, R.; Watson, O.J.; Mishra, S.; Walker, P.; Whittaker, C.; Katzourakis, A.; Donnelly, C.A.; Riley, S.; Ghani, A.C.; et al. Have Deaths from COVID-19 in Europe Plateaued Due to Herd Immunity? Lancet 2020, 395, e110-e111. [CrossRef]

5. Eades, S.; Eades, F.; McCaullay, D.; Nelson, L.; Phelan, P.; Stanley, F. Australia's First Nations' Response to the COVID-19 Pandemic. Lancet 2020, 396, 237-238. [CrossRef]

6. Salyer, S.J.; Maeda, J.; Sembuche, S.; Kebede, Y.; Tshangela, A.; Moussif, M.; Ihekweazu, C.; Mayet, N.; Abate, E.; Ouma, A.O.; et al. The First and Second Waves of the COVID-19 Pandemic in Africa: A Cross-Sectional Study. Lancet 2021, 397, 1265-1275. [CrossRef]

7. The Lancet. COVID-19 in the USA: A Question of Time. Lancet 2020, 395, 1229.

8. Day, M. COVID-19: Italy Confirms 11 Deaths as Cases Spread from North. BMJ 2020, 368, m757. [CrossRef]

9. ECDC. Novel Coronavirus Disease 2019 (COVID-19) Pandemic: Increased Transmission in the EU/EEA and the UK-Sixth Update-12 March 2020; European Centre for Disease Prevention and Control: Stockholm, Sweden, 2020.

10. Kwok, K.O.; Lai, F.; Wei, W.I.; Wong, S.Y.S.; Tang, J.W.T. Herd Immunity-Estimating the Level Required to Halt the COVID-19 Epidemics in Affected Countries. J. Infect. 2020, 80, e32-e33. [CrossRef]

11. Poljanšek, K.; Marin Ferrer, M.; De Groeve, T.; Clark, I. (Eds.) Science for Disaster Risk Management 2017: Knowing Better and Losing Less; European Commission: Luxembourg, 2017.

12. Tàbara, J.D.; Frantzeskaki, N.; Hölscher, K.; Pedde, S.; Kok, K.; Lamperti, F.; Christensen, J.H.; Jäger, J.; Berry, P. Positive Tipping Points in a Rapidly Warming World. Curr. Opin. Environ. Sustain. 2018, 31, 120-129. [CrossRef]

13. Haasnoot, M.; Kwakkel, J.H.; Walker, W.E.; ter Maat, J. Dynamic Adaptive Policy Pathways: A Method for Crafting Robust Decisions for a Deeply Uncertain World. Glob. Environ. Chang. 2013, 23, 485-498. [CrossRef]

14. Werners, S.E.; Pfenninger, S.; van Slobbe, E.; Haasnoot, M.; Kwakkel, J.H.; Swart, R.J. Thresholds, Tipping and Turning Points for Sustainability under Climate Change. Curr. Opin. Environ. Sustain. 2013, 5, 334-340. [CrossRef]

15. Paul, L.D.; Street, E.J.; Leslie, T.F.; Yang, Y.T.; Jacobsen, K.H. Complexity of the Basic Reproduction Number (R(0)). Emerg. Infect. Dis. 2019, 25, 1-4.

16. Gillespie, C. Coronavirus Experts Want to 'Flatten the Curve' to Fight the Pandemic-Here's What That Means. Available online: https:/ / www.health.com/condition/infectious-diseases/coronavirus/flatten-the-curve-meaning (accessed on 13 March 2020).

17. Hofstede, G.; Hofstede, G.-J.; Minkov, M. Cultures and Organizations-Software of the Mind: Intercultural Cooperation and Its Importance for Survival; Mc Graw-Hill: New York, NY, USA, 2010.

18. Andrea, R.; Remuzzi, G. COVID-19 and Italy: What Next? Lancet 2020, 395, 1225-1228. 
19. El País. Coronavirus Deaths Continue to Rise in Spain, with a Record 838 in 24 Hours. Available online: https:/ / english.elpais. com/society/2020-03-29/coronavirus-deaths-continue-to-rise-in-spain-with-new-record-838-in-last-24-hours.html (accessed on 29 March 2020).

20. Clément, M.; Roux, J.; Crépey, P. COVID-19: Forecasting Short Term Hospital Needs in France. medRxiv 2020. [CrossRef]

21. Van Nederland, H. Tekort Aan Ic-Bedden Dreigt: Nog Maar Een Paar Plekken Vrij Voor Coronapatiënten. Available online: https:/ / www.hartvannederland.nl/nieuws/2020/nog-maar-paar-ic-bedden-vrij/ (accessed on 28 March 2020).

22. AFP. Germany Ramps up Intensive Care and Hospital Capacity in Coronavirus Fight. Available online: https:/ www.thelocal. de/20200318/germany-ramps-up-intensive-care-and-hospital-capacity-in-coronavirus-fight (accessed on 18 March 2020).

23. Wolf, B. The Coronavirus in Austria \& Vienna I A New Normality. Available online: https:/ / metropole.at/coronavirus-in-austria / (accessed on 7 April 2020).

24. The Coronavirus in Austria \& Vienna I What Happened in March. Available online: https:/ / metropole.at/coronavirus-in-austriamarch/ (accessed on 31 March 2020).

25. Aftonbladet. Tabell: Här Finns Alla Platser På Intensiven. Available online: https:/ / www.aftonbladet.se/nyheter/a/AdMPyr/ sa-manga-platser-pa-intensiven-har-ditt-sjukhus (accessed on 1 May 2020).

26. ECDC. Data on Testing for Covid-19 by Week and Country. Available online: https://www.stelios67pi.eu/older/20210604.html (accessed on 2 February 2021).

27. Worldbank. Gdp (Current Us\$). 2020. Available online: https://data.worldbank.org/indicator/SP.POP.TOTL (accessed on 2 February 2021).

28. Worldbank. Gdp Growth (Annual \%). 2020. Available online: https://data.worldbank.org/indicator/SP.POP.TOTL (accessed on 2 February 2021).

29. Worldbank. Current Health Expenditure (\% of Gdp). 2020. Available online: https:// data.worldbank.org/indicator/SP.POP TOTL (accessed on 2 February 2021).

30. Worldbank. Total Population Database. 2020. Available online: https://data.worldbank.org/indicator/SP.POP.TOTL (accessed on 2 February 2021).

31. Worldbank. Population Ages 65 and above, Total. 2020. Available online: https://data.worldbank.org/indicator/SP.POP.TOTL (accessed on 2 February 2021).

32. Worldbank. Population Density (People Per Sq. Km of Land Area). 2020. Available online: https://data.worldbank.org/ indicator/SP.POP.TOTL (accessed on 2 February 2021).

33. Worldbank. Urban Population (\% of Total Population). 2020. Available online: https://data.worldbank.org/indicator/SP.POP. TOTL (accessed on 2 February 2021).

34. Paul, C.; Brown, B.; Majomi, P. Professional Identity in Community Mental Health Nursing: A Thematic Analysis. Int. J. Nurs. Stud. 2008, 45, 1055-1063.

35. Valerie, M.; Theuns, P.; Erstad, I.; Bernheim, J. The Best and Worst Times of Life: Narratives and Assessments of Subjective Well-Being by Anamnestic Comparative Self Assessment (Acsa) in the Eastern Cape, South Africa. Soc. Indic. Res. 2008, 89, 1-22.

36. Langellier, K.M.; Peterson, E.E. Performing Narrative: The Communicative Practice of Storytelling; Temple University Press: Philadelphia, PA, USA, 2004; pp. 7-31.

37. Van der Voorn, T.; Quist, J. Analysing the Role of Visions, Agency, and Niches in Historical Transitions in Watershed Management in the Lower Mississippi River. Water 2018, 10, 1845. [CrossRef]

38. Nicholas, P. Rational Choice, Structural Context, and Increasing Returns:A Strategy for Analytic Narrative in Historical Sociology. Sociol. Methods Res. 2005, 33, 349-382.

39. Denzin, N.K. The Research Act in Sociology; Aldine: Chicago, IL, USA, 1970.

40. Bryman, A. Social Research Methods; Oxford University Press: Oxford, UK, 2001.

41. Chiara, S. Coronavirus: Primi Due Casi in Italia. Available online: https://www.corriere.it/cronache/20_gennaio_30 / coronavirus-italia-corona-9d6dc436-4343-11ea-bdc8-faf1f56f19b7.shtml?refresh_ce-cp (accessed on 6 April 2020).

42. Anzolin, E.; Amante, A. First Italian Dies of Coronavirus as Outbreak Flares in North. Available online: https://www.reuters com/article/us-china-health-italy-idUSKBN20F0UI (accessed on 21 February 2020).

43. Coronavirus Outbreak Grows in Northern Italy, 16 Cases Reported in One Day. Available online: https://www.reuters.com/ article/ us-china-health-italy / coronavirus-outbreak-grows-in-northern-italy-16-cases-reported-in-one-day-idUSKBN20F0UI (accessed on 21 February 2020).

44. Ravizza, S. Coronavirus: Primi Casi a Milano. Cosa Sappiamo Dei Nuovi Contagi in Lombardia, Veneto E Piemonte [Coronavirus: First Case in Milan. What We Know About New Infections in Lombardy, Veneto and Piemont]. Available online: https: / / www.corriere.it/cronache/20_febbraio_22/coronavirus-italia-nuovi-contagi-lombardia-veneto-245e72d4-554011ea-8418-2150c9ca483e.shtml (accessed on 6 April 2020).

45. Ananasso, A.; de Stabile, E.; Gagliardi, G.; Matteucci, P. Coronavirus in Italia: Aggiornamento Ora Per Ora. La Repubblica (in Italian). 22 February 2020. Available online: https://www.repubblica.it/cronaca/2020/02/22/news/coronavirus_in_italia_ aggiornamento_ora_per_ora-249241616/ (accessed on 6 April 2020).

46. Riccioni, L.; Bertolini, G.; Giannini, A.; Vergano, M.; Gristina, G.; Livigni, S.; Petrini, F. Raccomandazioni di etica clinica per l'ammissione a trattamenti intensivi e per la loro sospensione, in condizioni eccezionali di squilibrio tra necessità e risorse disponibili. Recenti Progress. Med. 2020, 111, 207-211. 
47. BBC. Coronavirus: Northern Italy Quarantines 16 Million People. Available online: https://www.bbc.com/news/world-middleeast-51787238 (accessed on 8 March 2020).

48. News BBC. All of Italy to Be Placed on Coronavirus Lockdown. Available online: https://www.bbc.com/news/world-europe-51 810673 (accessed on 9 March 2020).

49. Chico, H.; Loveday, M. Italy Ramps up Coronavirus Lockdown, Merkel Warns Virus Could Infect Two-Thirds of Germany. Available online: https:/ /www.washingtonpost.com/world/europe/merkel-coronavirus-germany/2020/03/11/e276252a-63 99-11ea-8a8e-5c5336b32760_story.html (accessed on 6 April 2020).

50. Safi, M.; Giuffrida, A.; Farrer, M. Coronavirus: Italy Bans Any Movement inside Country as Toll Nears 5500. Available online: https:/ / www.theguardian.com/world/2020/mar/22/italian-pm-warns-of-worst-crisis-since-ww2-as-coronavirusdeaths-leap-by-almost-800 (accessed on 6 April 2020).

51. Fortuna, G. Pm Conte Dismisses Idea That Italy Will Resort to Eurozone Bailout Fund. Available online: https:/ /www.euractiv. com/section/health-consumers/short_news/italy-update-covid-19/1441629/ (accessed on 13 March 2020).

52. University Johns Hopkins. Coronavirus Covid-19 Global Cases by the Center for Systems Science and Engineering (Csse) at Johns Hopkins. Available online: https:/ /gisanddata.maps.arcgis.com/apps/opsdashboard/index.html\#/bda7594740fd4029942 3467b48e9ecf6 (accessed on 6 April 2020).

53. Linde, P. Sanidad Confirma En La Gomera El Primer Caso De Coronavirus En España. Available online: https://elpais.com/ sociedad/2020/01/31/actualidad/1580509404_469734.html (accessed on 6 April 2020).

54. Colman, A. Spain Recorded 950 Coronavirus Deaths in a Day, the Highest Single-Day Toll of Any Country. Available online: https: / / www.businessinsider.com/ coronavirus-spain-950-deaths-one-day-most-of-any-country-2020-4 (accessed on 6 April 2020).

55. Abbonati, A. Coronavirus, Positivi Due Italiani a Tenerife. Mille Persone Nell'hotel in Quarantena. Available online: https: //www.repubblica.it/esteri/2020/02/25/news/coronavirus_contagiati_in_italia-249569108/(accessed on 6 April 2020).

56. de Sanidad, M. Actualización N ${ }^{\circ}$ 67. Enfermedad Por El Coronavirus (COVID-19). Edited by Centro de Coordinación de Alertas y Emergencias Sanitarias. Available online: https://www.mscbs.gob.es/profesionales/saludPublica/ccayes/alertasActual/ nCov/documentos/Actualizacion_67_COVID-19.pdf. (accessed on 20 April 2020).

57. Gallardo, C. Spain Unveils €200b Package to Combat Virus Downturn. Available online: https://www.politico.eu/article/spain200-billion-euros-package-virus-downturn/ (accessed on 17 March 2020).

58. Politico. How Europe Is Responding to the Coronavirus Pandemic Politico's Country-by-Country Guide to Health, Travel and Economic Measures. Available online: https:/ / www.politico.eu/article/how-europe-is-responding-to-the-coronaviruspandemic/ (accessed on 13 March 2020).

59. van Landbouw, M.; en Voedselkwaliteit, N. Spanish Government Greenlights €200 Billion to Mitigate COVID-19 Impact on Economy. Available online: https://www.agroberichtenbuitenland.nl/actueel/nieuws/2020/03/19/spanish-governmentgreenlights-€200-billion-to-mitigate-covid-19-impact-on-economy (accessed on 19 March 2020).

60. Lee, Y.N.; Ellyatt, H. Spain's Cases Surpass 11,000; Iran Temporarily Frees 85,000 Prisoners. Available online: https:/ /www.cnbc. com/2020/03/17/ coronavirus-latest-updates.html (accessed on 16 March 2020).

61. Euractiv. State of Alarm to Be Extended; Measures Appear to Be Paying Off. Available online: https://www.euractiv.com/ section/coronavirus/short_news/spain-update-covid-19/ (accessed on 13 March 2020).

62. Threadgould, J. Spain Passes China COVID-19 Death Toll, 2nd Behind Italy. Available online: https://www.laprensalatina.com/ spain-passes-china-covid-19-death-toll-2nd-behind-italy/ (accessed on 25 March 2020).

63. Gotev, G. Spanish Doctors, Nurses Demand Action after Coronavirus Cases Soar. Available online: https://www.euractiv.com/ section/coronavirus/news/spanish-doctors-nurses-demand-action-after-coronavirus-cases-soar/ (accessed on 25 March 2020).

64. RKI. Situation Report of the Robert Koch Institute Covid-19. 31/03/2020-Updated Status for German. Robert Koch Inst. 2020. Available online: https:/ /www.rki.de/DE/Content/InfAZ/N/Neuartiges_Coronavirus/Situationsberichte/2020-04-06-en.pdf? _blob=publicationFile (accessed on 2 February 2021).

65. Jones, S.; Kassam, A. Spain Defends Response to Coronavirus as Global Cases Exceed 500,000. Available online: https:// www.theguardian.com/world/2020/mar/26/spanish-coronavirus-deaths-slow-as-world-nears-500000-cases (accessed on 26 March 2020).

66. Marcos, J. Spanish Government Tightens Lockdown to Include All Non-Essential Workers. Available online: https: / english. elpais.com/politics/2020-03-28/spanish-government-tightens-lockdown-to-include-all-non-essential-workers.html (accessed on 29 March 2020).

67. The Straits Times. Wuhan Virus: France Confirms Fourth Case of Coronavirus in Elderly Chinese Tourist. Available online: https:/ / www.straitstimes.com/world/europe/france-confirms-fourth-case-of-coronavirus-in-elderly-chinese-tourist (accessed on 29 January 2020).

68. BBC. Coronavirus: First Death Confirmed in Europe. Available online: https://www.bbc.com/news/world-europe-51514837 (accessed on 15 February 2020).

69. The Connexion. Stage 3 Covid-19 Epidemic 'Inevitable' in France. Available online: https://wuhanupdate.com/health/stage-3covid-19-epidemic-inevitable-in-france-84060864 (accessed on 7 March 2020).

70. Euractiv. France 'Headed for Worst Year of Economic Recession since End of World War Ii'. Available online: https://www. euractiv.com/section/health-consumers/short_news/france-update-covid-19/ (accessed on 13 March 2020). 
71. The Local France. France Bans Gatherings of More Than 100 People as Coronavirus Death Toll Rises. Available online: https: / / www.thelocal.fr/20200313/france-bans-gatherings-of-over-100-people-to-fight-coronavirus-pandemic (accessed on 13 March 2020).

72. Barbiere, C. After Declaring 'War' on Covid-19, France Readies Measures to Uphold Economy. Available online: https://www. euractiv.com/section/coronavirus/news/after-declaring-war-on-covid-19-france-readies-measures-to-uphold-economy/ (accessed on 18 March 2020).

73. RFI. France to Step up Coronavirus Testing Methods as Death Toll Climbs. Available online: http://www.rfi.fr/en/france/2020 0318-france-step-up-coronavirus-new-test-methods-death-toll-climbs-covid-19-priority-risk-elderly-symptoms (accessed on 18 March 2020).

74. Reuters. Twitter, “Dutch Prime Minster Mark Rutte Advised People to Not Shake Hands at a \#Coronavirus Press Conference on Monday, but Went on to Do Exactly that Moments Later". Available online: https://twitter.com/Reuters/status/12373424365334 20034 (accessed on 10 March 2020).

75. van Nederland, H. Geen Lockdown, Wel Scherpere Corona-Maatregelen: Boetes Voor Geen Afstand Houden. Available online: https: / / www.hartvannederland.nl/nieuws/2020/persconferentie-kabinet-coronacrisis/ (accessed on 7 April 2020).

76. NOS. Ic-Arts Gommers: Binnen Een Week Moeten 2400 Bedden Gereed Zijn. Available online: https://nos.nl/artikel/2328827-icarts-gommers-binnen-een-week-moeten-2400-bedden-gereed-zijn.html (accessed on 7 April 2020).

77. Pieters, J. Icu Staff Stressed and Overworked in Coronacrisis. Available online: https://nltimes.nl/2020/04/01/icu-staff-stressedoverworked-coronacrisis (accessed on 7 April 2020).

78. van der Aa, E.; Bolt, R. Ic-Voorzitter Gommers Vreest 'Italiaanse Toestanden'. Available online: https://www.ad.nl/politiek/icvoorzitter-gommers-vreest-italiaanse-toestanden \{\}a99030f3/ (accessed on 7 April 2020).

79. Eck, D. Dutch Government Extends 'Intelligent Lockdown', Proposes Eu Emergency Corona-Fund without Conditions. Available online: https:/ / www.euractiv.com/section/coronavirus/short_news/netherlands-update-covid-19/ (accessed on 7 April 2020).

80. NOS. Van Dissel: Volhouden Beperkende Maatregelen Is Cruciaal. Available online: https://nos.nl/artikel/2329035-van-disselvolhouden-beperkende-maatregelen-is-cruciaal.html (accessed on 1 April 2020).

81. Spiegel, D. Bayerische Behörden Bestätigen Ersten Fall in Deutschland. 2020. Available online: https://www.spiegel.de/ wissenschaft/medizin/ corona-virus-erster-fall-in-deutschland-bestaetigt-a-19843b8d-8694-451f-baf7-0189d3356f99 (accessed on 7 April 2020).

82. Anderl, S. Fallsterblichkeitsrate: Wie Tödlich Ist Covid-19 in Deutschland? Available online: https://www.faz.net/aktuell/ politik/inland/wie-toedlich-ist-das-coronavirus-in-deutschland-16711071.html (accessed on 4 April 2020).

83. Die Rheinpfalz. Corona-Virus: Bundesregierung Hält Risiko Für Deutschland Sehr Gering. Available online: https://www. rheinpfalz.de/panorama_artikel,-corona-virus-bundesregierung-hält-risiko-für-deutschland-sehr-gering-_arid,1579340.html (accessed on 27 January 2020).

84. O'Brien, C. Us Commander: Coronavirus Could Restrict Troop Travel in Germany. Available online: https://www.politico. eu/article/us-commander-says-troop-travel-in-germany-could-be-restricted-amid-coronavirus-outbreak/ (accessed on 25 February 2020).

85. Heinsberg, K. Aktuelles Aus Dem Kreishaus. Available online: https://www.kreis-heinsberg.de/aktuelles/aktuelles/?pid=5136 (accessed on 29 February 2020).

86. Abendblatt, H. Coronavirus: Zwei Tote in Deutschland-Italien Sperrt Das Ganze Land. Available online: https://www. abendblatt.de/vermischtes / article228637475/Coronavirus-Corona-News-Live-Ticker-Covid-19-Tote-in-Deutschland-1164 -Infektionen.html (accessed on 9 March 2020).

87. Die Welt. Bundesregierung Legt Krisen-Leitlinien Fest-Merkel Für Vorgehen Mit Maß Und Mitte. Available online: https:/ / www.welt.de/vermischtes/article206221797/Coronavirus-Bundesregierung-legt-Krisen-Leitlinien-fest-Merkel-fuerVorgehen-mit-Mass-und-Mitte.html (accessed on 29 February 2020).

88. RKI. Sars-Cov-2: Fallzahlen in Deutschland, China Und Weltweit. Available online: http://web.archive.org/web/202003030831 52/https://www.rki.de/DE/Content/InfAZ/N/Neuartiges_Coronavirus/Fallzahlen.html (accessed on 2 March 2020).

89. ARD. Jeder Muss Seinen Beitrag Leisten. Available online: https://www.tagesschau.de/inland/coronavirus-spahn-rki-105.html (accessed on 9 March 2020).

90. Financial Times. Germany Wields 'Bazooka' in Fight against Coronavirus. Available online: https://www.ft.com/content/1b0f0 324-6530-11ea-b3f3-fe4680ea68b5 (accessed on 13 March 2020).

91. Carrel, P. Germany Discussing Its Medical Export Restrictions with Eu Partners. Available online: https://www.reuters.com/ article/us-health-coronavirus-germany-ventilator/germany-discussing-its-medical-export-restrictions-with-eu-partnersidUSKBN2101IU (accessed on 13 March 2020).

92. Bartsch, M.; Blech, J.; Bruhns, A.; Eberle, L.; Elger, K.; Feldenkirchen, M.; Gnirke, K.; Großbongardt, A.; Gude, H.; Hackenbroch, V.; et al. Are Hospitals Ready for the Coming Wave of Corona Cases? Available online: https://www.spiegel.de/international/ germany/the-big-wave-of-corona-cases-will-hit-german-hospitals-in-10-to-14-days-a-45cd754c-e179-4dbb-8caf-8f6074e641cf (accessed on 21 March 2020).

93. BBC. Coronavirus: Germany to Impose Border Controls over Coronavirus. Available online: https://www.bbc.com/news / world-europe-51897069 (accessed on 15 March 2020). 
94. Mappes, F.W. Erster Fall Im Landkreis Bad Dürkheim: Corona-Virus in Wachenheim Bestätigt. Available online: https: / / www.wochenblatt-reporter.de/bad-duerkheim/c-lokales/corona-virus-in-wachenheim-bestaetigt_a176479 (accessed on 4 March 2020).

95. ARD. Bundesweite Ausgangssperre Rückt Näher. Available online: https://www.tagesschau.de/inland/corona-lockdown-nachweihnachten-101.html (accessed on 20 March 2020).

96. Marcus, I. Germany Steps up Fight against Coronavirus. Available online: https://berlinspectator.com/2020/03/11/germanysteps-up-fight-against-coronavirus / (accessed on 11 March 2020).

97. Stam, C.; Grüll, P.; Lawton, S. Progress in Germany as the Number of New Infections Decrease. Available online: https: //www.euractiv.com/section/health-consumers/short_news/germany-coronavirus-update/ (accessed on 13 March 2020).

98. von Lars, W. Ischgl War Die Heimliche Virus-Drehscheibe in Europa. Available online: https://www.t-online.de/nachrichten/ panorama/id_87525436/coronavirus-von-ischgl-verbreitete-sich-covid-19-in-ganz-europa.html (accessed on 4 December 2020).

99. Grüll, P. How an Austrian Ski Paradise Became a Covid-19 Hotspot. Available online: https://www.euractiv.com/section/ coronavirus/news/ischgl-oesterreichisches-skiparadies-als-corona-hotspot/ (accessed on 20 March 2020).

100. Bazaraa, D. Coronavirus: Ibiza of the Alps' Ski Village Blamed for Hundreds of Cases in Europe. Available online: https: / / www.mirror.co.uk/news/world-news/coronavirus-ibiza-alps-ski-village-21739316 (accessed on 23 March 2020).

101. Groendahl, B. Austria Closes Passage from Italy without Health Clearance. Available online: https://www.bloomberg.com/ news / articles/2020-03-10/austria-closes-border-for-italians-without-health-clearance (accessed on 10 March 2020).

102. Sebastiankurz. Mein Appell Ist in Der Derzeitigen Situation Klar: Nehmen Sie Die Situation Ernst Und Glauben Sie Den Beschwichtigungen Nicht! Nur Gemeinsam Können Wir Die Ausbreitung Des Coronavirus Verlangsamen. 2020. Available online: https:/ / www.wienerzeitung.at/nachrichten/politik/oesterreich/2054402-Coronavirus-Parlament-beschliesst-Gesetzefuer-Massnahmen.html (accessed on 4 March 2020).

103. Grüll, P. Austria's Government Presents Covid-19 Exit Schedule. Available online: https://www.euractiv.com/section/ coronavirus/news/austrias-government-presents-covid-19-exit-schedule/ (accessed on 6 April 2020).

104. Grüll, P.; Lawton, S. Government Presents First Steps of Exit Strategy, Wants to Ease Lockdown Ahead of Others. Available online: https:/ / www.euractiv.com/section/health-consumers/short_news/austria-update-covid-19/1441621/ (accessed on 13 March 2020).

105. Knolle, K. Austria Bets on Mass Testing to Manage Coronavirus Spread. Available online: https://www.reuters.com/article/ushealth-coronavirus-austria/austria-bets-on-mass-testing-to-manage-coronavirus-spread-idUSKBN21B1DH (accessed on 24 March 2020).

106. Boseley, S.; Campbell, D.; Murphy, S. First British National to Contract Coronavirus Had Been in Singapore. Patient Diagnosed in Brighton and Taken to London Is Third Confirmed Case in the UK. Available online: https://www.theguardian.com/world/20 20/feb/06/third-person-in-uk-confirmed-as-having-coronavirus (accessed on 6 February 2020).

107. Mohdin, K.; Willsher, A.; Madrid, A.; Jones, S. Coronavirus: British Nine-Year-Old in Hospital in France. Available online: https:/ / www.theguardian.com/world/2020/feb/08/coronavirus-five-new-cases-in-france-are-british-nationals (accessed on 26 February 2020).

108. BBC. Coronavirus: Brighton Gp Practice Closes after Staff Member Tests Positive. Available online: https://www.bbc.com/ news / uk-51447761 (accessed on 11 February 2020).

109. Elisabeth, M. Coronavirus: Nhs Staff Get Power to Keep Patients in Isolation as UK Declares Serious Threat. BMJ 2020, $368,550$.

110. O’Regan, E.; Doyle, K.; Edwards, M.; Bray, A. Coronavirus Ireland: Passengers Who Travelled with Northern Irish Patient Traced in Bid to Prevent Outbreak. Available online: https://www.independent.ie/world-news/coronavirus/coronavirusireland-passengers-who-travelled-with-northern-irish-patient-traced-in-bid-to-prevent-outbreak-38997601.html (accessed on 28 March 2020).

111. England Department of Health and Social Care and Public Health. Coronavirus (COVID-19): Latest Information and Advice. Available online: https:/ / www.gov.uk/guidance/coronavirus-covid-19-information-for-the-public (accessed on 24 January 2020).

112. BBC. Coronavirus Could Spread 'Significantly'—Pm. Available online: https://www.bbc.com/news/uk-51708550 (accessed on 2 March 2020).

113. Russell, P. New Coronavirus: UK Public Health Campaign Launched. Available online: https://www.medscape.com/ viewarticle/924664 (accessed on 3 February 2020).

114. Ross, T.; Donaldson, K.U.K. Abandons Effort to Contain Virus as 10,000 May Be Infected. Available online: https://www. bloomberg.com/news/articles/2020-03-12/u-k-abandons-effort-to-contain-virus-moves-to-delay-the-worst (accessed on 12 March 2020).

115. BBC. Coronavirus: Britons Returning from Northern Italy Told to Self-Isolate. Available online: https://www.bbc.com/news/ uk-51625733 (accessed on 26 February 2020).

116. Rayner, G. Government Takes over Heathrow Hotel to House Quarantined Travellers as They Arrive Travellers Are Being Advised to Board Flights Back to Their Country of Origin If They Are Not Prepared to Self-Isolate. Available online: https: //www.telegraph.co.uk/news/2020/03/10/government-takes-heathrow-hotel-house-quarantined-travellers/ (accessed on 10 March 2020). 
117. Knapton, S. Hospitals Could Run Short of Oxygen 'within Hours' as Coronavirus Escalates, Specialists Warn 'Overwhelmed' Service Also in Danger of Running out of Medication and Beds as Expected Cases Exceed One Million. Available online: https: / / www.telegraph.co.uk/news/2020/03/15/hospitals-could-run-short-oxygen-within-hours-pandemic-escalates / (accessed on 15 March 2020).

118. Flaxman, S.; Mishra, S.; Gandy, A. Estimating the Number of Infections and the Impact of Non-Pharmaceutical Interventions on Covid-19 in 11 European Countries. Imp. Coll. Lond. 2020, 584, 257-261. [CrossRef] [PubMed]

119. Nair, A. Coronavirus: London Worst Affected by Outbreak-621 Cases, 25 Deaths. Available online: https://news.sky.com/story/ uk-coronavirus-cases-reach-1-950-up-407-in-24-hours-11958875 (accessed on 18 March 2020).

120. Ministry of Housing, Communities \& Local Government. Coronavirus (COVID-19): Guidance for Local Government Guidance for Local Councils during the Coronavirus (COVID-19) Outbreak. Available online: https://www.gov.uk/guidance/coronaviruscovid-19-guidance-for-local-government (accessed on 17 March 2020).

121. MP, HM Treasury and The Rt Hon Rishi Sunak. The Chancellor Rishi Sunak Provides an Updated Statement on Coronavirus the Chancellor Unveiled Today (20 March) a Further Series of Measures to Support People, Jobs and Businesses. Available online: https: / / www.gov.uk/government/speeches/the-chancellor-rishi-sunak-provides-an-updated-statement-on-coronavirus (accessed on 20 March 2020).

122. BBC. Coronavirus: Tens of Thousands of Retired Medics Asked to Return to Nhs. Available online: https://www.bbc.com/ news/uk-51969104 (accessed on 20 March 2020).

123. Neslen, A. UK Foreign Secretary Appointed 'Designated Survivor' If Boris Johnson Catches COVID-19. Available online: https: / / www.politico.eu/article/uk-foreign-secretary-appointed-designated-survivor-if-boris-johnson-catches-covid-19/ (accessed on 22 March 2020).

124. Fox, B. London-Government Seeks 250,000 Nhs Volunteer Force. Available online: https://www.euractiv.com/section/all/ short_news/london-government-seeks-250000-nhs-volunteer-force/ (accessed on 25 March 2020).

125. Triggle, N. Coronavirus: Is the Nhs Ready for the Surge in Cases? Available online: https://www.bbc.com/news/health-51714498 (accessed on 3 April 2020).

126. Schraer, R. Coronavirus: Excel Centre Planned as Nhs Field Hospital. Available online: https://www.bbc.com/news/health-52 018477 (accessed on 24 March 2020).

127. BBC. Coronavirus: Thousands of Extra Hospital Beds and Staff. Available online: https://www.bbc.com/news/uk-51989183 (accessed on 21 March 2020).

128. Coronavirus: UK Deaths Rise by More Than 100 in a Day. Available online: https://www.bbc.com/news/uk-52056534 (accessed on 26 March 2020).

129. Zimmermann, B.; Fiske, A.; McLennan, S.; Sierawska, A.; Hangel, N.; Buyx, A. Motivations and Limits for COVID-19 Policy Compliance in Germany and Switzerland. Int. J. Health Policy Manag. 2021. [CrossRef] [PubMed]

130. Gibney, E. Whose Coronavirus Strategy Worked Best? Scientists Hunt Most Effective Policies. Nature 2020, 581, 15-16. [CrossRef] [PubMed]

131. Prosun, B.; Kumar, M.; Islam, M.T.; Haque, R.; Chakraborty, S.; Ahmad, A.; Niazi, N.K.; Cetecioglu, Z.; Nilsson, D.; Ijumulana, J.; et al. Prevalence of Sars-Cov-2 in Communities through Wastewater Surveillance-A Potential Approach for Estimation of Disease Burden. Curr. Pollut. Rep. 2021, 7, 160-166.

132. Van der Voorn, T.; Caroline van den, B.; Prosun, B.; Jaco, Q. Never Waste a Crisis: Drawing First Lessons from the COVID-19 Pandemic to Tackle the Water Crisis. ACS EST Water 2020, 1, 8-10. [CrossRef]

133. Aaron, B.; North, D.; Ahmad, A.; Ahmed, W.; Alm, E.; Been, F.; Bhattacharya, P.; Bijlsma, L.; Boehm, A.B.; Brown, J.; et al. Wastewater-Based Epidemiology: Global Collaborative to Maximize Contributions in the Fight against COVID-19. Environ. Sci. Technol. 2020, 54, 7754-7757.

134. Clement, D. Estimating Economic Impact of Covid-19. Summary of Minneapolis Fed Staff Report: "What Will Be the Economic Impact of COVID-19 in the U.S? Rough Estimates of Disease Scenarios. Available online: https:/ / www.minneapolisfed.org/ article/2020/estimating-economic-impact-of-covid-19 (accessed on 19 March 2020).

135. EUR. The Impact of Covid-19 on the Dutch Economy. Bas Jacobs, Sijbren Cnossen Professor of Public Economics at Erasmus School of Economics, Discusses the Impact of the Coronavirus on the Dutch Economy on Npo Radio 1 Programme Stax \& Toine. NPO Radio1. Available online: https://www.eur.nl/en/news/impact-covid-19-dutch-economy (accessed on 20 March 2020). 